Article

\title{
Bioactive Potential of 2-Methoxy-4-vinylphenol and Benzofuran from Brassica oleracea L. var. capitate $f$, rubra (Red Cabbage) on Oxidative and Microbiological Stability of Beef Meat
}

\author{
Momna Rubab ${ }^{1}$, Ramachandran Chelliah ${ }^{1}$, Kandasamy Saravanakumar ${ }^{2}{ }^{\mathbb{D}}$, \\ Kaliyan Barathikannan ${ }^{1}$ (D), Shuai Wei ${ }^{3}$, Jong-Rae Kim ${ }^{1,4}$, Daesang Yoo 1,5, \\ Myeong-Hyeon Wang ${ }^{2}$ and Deog-Hwan Oh ${ }^{1, *}$ \\ 1 Department of Food Science and Biotechnology, College of Agriculture and Life Sciences, \\ Kangwon National University, Chuncheon 200-701, Korea; rubab.momna@gmail.com (M.R.); \\ ramachandran865@kangwon.ac.kr (R.C.); bkannanbio@gmail.com (K.B.); chief1111@daum.net (J.-R.K.); \\ daesangy@naver.com (D.Y.) \\ 2 Department of Medical Biotechnology, College of Biomedical Sciences, Kangwon National University, \\ Chuncheon 200-701, Korea; saravana732@gmail.com (K.S.); mhwang@kangwon.ac.kr (M.-H.W.) \\ 3 College of Food Science and Technology, Guangdong Ocean University, Zhanjiang 524088, China; \\ weis@gdou.edu.cn \\ 4 Hanmi Natural Nutrition Co., LTD 44-20, Tongil-ro 1888 beon-gil, Munsan, Paju, Gyeonggi 10808, Korea \\ 5 H-FOOD, 108-66, 390 gil, Jingun Oh Nam-Ro, Nam Yang, Ju-Shi, Gyung Gi-Do 12041, Korea \\ * Correspondence: deoghwa@kangwon.ac.kr; Fax: +82-(0)3-3259-5565
}

Received: 1 April 2020; Accepted: 15 April 2020; Published: 4 May 2020

\begin{abstract}
In the future, plant based phytochemicals will be considered as efficient replacement sources of chemical preservatives, to act as potential bio-preservatives. We investigated the antibacterial and antioxidant activity of red cabbage (RC) extracts using different solvents. Among all extracts, chloroform extract exhibited strong antimicrobial and antioxidant activities. Hence, the phytochemical constitutions of the RC chloroform extract was examined by GC-MS analysis, and further, based on molecular docking analysis, revealed 2-Methoxy-4-vinylphenol and benzofuran as two major compounds found to be possessing higher degrees of interaction with DNA gyrase (4PLB; $-8.63 \mathrm{Kcal}^{-\mathrm{mol}^{-1}}$ ) and lipoprotein (LpxC-8.229 Kcal.mol ${ }^{-1}$ ), respectively, of the bacterial cell wall, which leads to higher antimicrobial efficacy. Further, it was confirmed with that the in vivo Caenorhabditis elegans model (but no cytotoxic effect) was exhibited in the MCF-7 cell line. Thus, we investigated the influence of this extract on the shelf life of meat under refrigeration storage. The physicochemical properties were observed periodically, and microbial analysis was conducted. The shelf life of the beef was enhanced (up to eight days) in terms of microbial and physiochemical properties, at $4 \pm 2{ }^{\circ} \mathrm{C}$ when compared to control. We concluded that chloroform extract of RC has potential as a natural preservative in the meat processing industry.
\end{abstract}

Keywords: red cabbage (RC); phytochemicals; antimicrobial; C. elegans; cytotoxicity; beef preservation

\section{Introduction}

In the 21th century, for consumers in both European and Asian countries, there has been increasing demand for meat products based on their beneficial health effects. However, they are vulnerable to microbial spoilage due to the high moisture content and enriched nutrition profile [1]. The increasing need for meat products has led to the development of preservation technology; this prevents food spoilage and improves public health research [2]. Dysentery pathogens, including the toxin-producing 
Enterobacteriaceae group, are mainly responsible for causing meat spoilage [3]. To ensure food safety, a variety of synthetic additives and chemical preservatives are extensively applied in the meat industry [4]. The positive aspects of chemical preservatives executes efficient antimicrobial effects against foodborne pathogens and predominantly extends the storage life of the meat products; however, the negative side effects of chemical preservative leads to numerous health problems [4]. Nowadays, consumers question the safety of chemical and synthetic preservatives in food, as well as the health effects. Therefore, considerable efforts have been made to restrict the use of chemical preservatives in food applications, which are impregnable for consumer health [5]. This has opened a new dimension for the application of bio-preservatives based on natural plant-derived phytochemical preservatives towards antimicrobial and antioxidant activities in food. The majority of laboratories across the globe are involved in systematic screening of plant species for revealing new bioactive compounds. Therefore, there is a need for scientific affirmation of bioactive compounds [4]. Numerous edible and herbal plants were screened for antimicrobial activity in recent times [5]. Natural products can be beneficial for inhibition of both microbial and oxidation-induced food spoilage since they exhibit both antimicrobial and antioxidant activities. Plants were considered ample sources of the wide range of secondary metabolites responsible for antimicrobial potential, such as tannins, terpenoids, alkaloids, and flavonoids [5].

Brassica oleracea L. var. capitate f, rubra, commonly known as red cabbage (RC), and belonging to the family Brassicaceae, is one of the most important vegetables grown globally. The lack of studies regarding in vitro antioxidant and antimicrobial potential of RC has prompted the current research. Therefore, the aim of this work was to investigate the antimicrobial and antioxidant potential of RC extracts using different solvents in vitro. Based on in vitro results, extract with strong antimicrobial and antioxidant ability was subject to cytotoxic evaluation, to assess its safety index and GC-MS analysis, coupled with molecular docking, to identify the potential bioactive lead compound(s) responsible for its biological activities. To investigate the potential of using the active RC extract as a natural preservative, we selected beef meat as a model in raw meat systems, and studied shelf life extension properties for 16 days at $4{ }^{\circ} \mathrm{C}$.

\section{Materials and Methods}

\subsection{Extraction Procedure}

Fresh cabbage heads were randomly procured from the local market in South Korea and then transported to the laboratory. The stem of cabbage was removed, and the leaves were washed and dried at $75^{\circ} \mathrm{C}$ oven temperature, and pulverized into a fine powder using a stainless steel blender. The $2 \mathrm{~g}$ of ground powder was subject to extraction in each bottle, having different solvents (toluene, diethyl ether, chloroform, dichloromethane, ethanol, methanol, and distilled water; $50 \mathrm{~mL}$ for each) at room temperature (RT) for $24 \mathrm{~h}$ with continuous stirring at $150 \mathrm{rpm}$. Extracts were then evaporated using a vacuum rotary evaporator. The samples were collected by using dimethyl sulfoxide (DMSO) for non-polar extracts (chloroform, dichloromethane, diethyl ether, and toluene) and distilled water for polar extracts (ethanol, methanol and distilled water), by stirring for $3 \mathrm{~h}$ using a magnetic stirrer following evaporation. After that, extracts were separated from the residue through a centrifuge for $30 \mathrm{~min}$ with $4000 \mathrm{rpm}$ and stored at $4{ }^{\circ} \mathrm{C}$ until use.

\subsection{Total Phenol (TP), Total Flavonoid (TF) Content, and Antioxidant Activity of Red Cabbage}

\subsubsection{TP and TF Content}

The total phenol (TP) and total flavonoid (TF) were measured spectrophotochemically using the Folin-Ciocalteu (F-C) method of Rubab et al. [6]. Briefly, $2.5 \mathrm{~mL}$ of $10 \%$ Folin-Ciocalteu reagent was added to the $0.5 \mathrm{~mL}$ of the extract and a standard solution of gallic acid (GA). The solutions were incubated at RT for $3 \mathrm{~min}$, after which $2.5 \mathrm{~mL}$ of $7.5 \% \mathrm{NaHCO}_{3}$ was added and incubated again for $90 \mathrm{~min}$ in the 
dark. The absorbance was observed at $765 \mathrm{~nm}$ and TP content expressed as $\mathrm{mg}$ of GA equivalent per $\mathrm{g}$ dried RC. For TF content, $100 \mu \mathrm{L}$ of $2 \%$ aluminum chloride was added to $250 \mu \mathrm{L}$ of the extract and a standard of quercetin. The solutions were incubated at RT for $1 \mathrm{~h}$ and absorbance was observed at $415 \mathrm{~nm}$. The TF content was expressed as mg of quercetin equivalent per $\mathrm{g}$ dried RC ( $\left.\mathrm{mg} \mathrm{QE} \mathrm{g}^{-1}\right)$.

\subsubsection{Antioxidant Activity Assays}

The radical scavenging activities of the cabbage extracts were quantified using 2,2'-azino-bis(3ethylbenzothiazoline-6-sulfonic acid (ABTS) and 1-diphenyl-2-picrylhydrazyl (DPPH) radical as a reagent, by the method of Rubab et al. [6]. The absorbance was observed at $517 \mathrm{~nm}$ in DPPH assay. The DPPH radical scavenging activity was described as inhibition percentage and scavenging capability was figured as follows;

$$
\text { DPPH scavenging effect }(\% \text { inhibition })=\frac{\mathrm{A}_{0}-\mathrm{A}_{1}}{\mathrm{~A}_{0}} \times 100
$$

where $A_{0}$ is the absorbance of the control (only DPPH without sample) and $A_{1}$ is the absorbance with the sample and the reference.

In ABTS assay, absorbance was observed at $734 \mathrm{~nm}$. The ABTS scavenging activity was exhibited as inhibition percentage and scavenging capability was figured as follows:

ABTS radical scavenging activity $(\%)=($ A control - A extracts $) /$ A control $\times 100$

\subsection{GC-MS Analysis}

GC-MS analysis was conducted by using an Agilent 7890 A, 5975C system equipped with an Agilent capillary column HP DB-5 $(30 \times 0.25 \mathrm{~mm}$; film thickness $0.25 \mu \mathrm{m})$ method of Bakari et al. [7], with some modifications. The temperature program was set from 50 to $280{ }^{\circ} \mathrm{C}$ at a rate of $5{ }^{\circ} \mathrm{C} \cdot \mathrm{min}^{-1}$, with the split ratio of 10:1. GC-MS was operated in a continual flow mode $5.0 \mathrm{~mL}$. $\mathrm{min}^{-1}$. The injection volume was $2 \mu \mathrm{L}$ and hydrogen was used as carrier gas. The identified compounds were detected by comparing the mass spectra with those of valid samples acquired by MS library.

\subsection{Antimicrobial Activity}

\subsubsection{Microorganisms}

A total of 7 bacterial strains and 4 fungal strains were used to investigate the antimicrobial potential of RC extracts (Table 1). All bacterial strains were subculture in nutrient broth (NB) and fungal strains in De Man, Rogosa, and Sharpe (MRS) broth at $37^{\circ} \mathrm{C}$ and $30^{\circ} \mathrm{C}$ for $24 \mathrm{~h}$, respectively.

\subsubsection{Antimicrobial Assay}

Disc diffusion method was used to screen the antimicrobial activities of different RC extracts. Gentamicin $\left(30 \mu \mathrm{g} \cdot \mathrm{disc}^{-1}\right)$ and sodium metabisulfite was employed as positive control and DMSO as negative control. Briefly, $100 \mu \mathrm{L}$ of fresh bacterial or fungi culture was pipetted in the center of agar plates (Muller-Hinton agar (MHA) for bacterial and De Man, Rogosa, and Sharpe (MRS) for fungal strains). Then, Whatman filter paper discs $(8 \mathrm{~mm})$ were aseptically placed on the surface of agar with $100 \mu \mathrm{L}$ of RC extracts. The MHA and MRS agar plates were incubated at $37^{\circ} \mathrm{C}$ and $30^{\circ} \mathrm{C}$ for $24 \mathrm{~h}$, respectively, and examined for inhibition zones. Antimicrobial activity was determined by measuring zone of inhibition (including the disc diameter). Antimicrobial test for all microorganisms were conducted in triplicate ( 3 petri dishes) and the results described, herein, are mean values of 3 petri dishes. Only samples with strong antimicrobial activity were used to evaluate the minimum inhibitory concentration. 
Table 1. Antimicrobial activity of different extracts of red cabbage (RC).

\begin{tabular}{|c|c|c|c|c|c|c|c|}
\hline \multirow{2}{*}{$\begin{array}{c}\text { List of } \\
\text { Microorganisms }\end{array}$} & \multicolumn{7}{|c|}{ Zone of Inhibition Diameter (mm) } \\
\hline & CE & TE & DE & EEE & EtE & ME & DWE \\
\hline \multicolumn{8}{|c|}{ Gram-negative bacteria } \\
\hline $\begin{array}{c}\text { Salmonella. enterica } \\
\text { typhimurium } \\
\text { ATCC } 14,028\end{array}$ & $12.00 \pm 0.01^{\mathrm{b}}$ & $12.00 \pm 0.04^{\mathrm{b}}$ & $10.00 \pm 0.02^{\mathrm{a}}$ & - & $11.00 \pm 0.03^{\mathrm{ab}}$ & $10.00 \pm 0.05^{\mathrm{a}}$ & - \\
\hline $\begin{array}{l}\text { Escherichia. coli ATCC } \\
\qquad 35,150\end{array}$ & $13.00 \pm 0.02^{\mathrm{c}}$ & $11.00 \pm 0.03^{\mathrm{b}}$ & $10.00 \pm 0.05^{\mathrm{ab}}$ & - & $10.00 \pm 0.05^{\mathrm{ab}}$ & $09.00 \pm 0.06^{\mathrm{a}}$ & - \\
\hline $\begin{array}{l}\text { Escherichia. coli ATCC } \\
\qquad 43,894\end{array}$ & $11.00 \pm 0.03^{\mathrm{b}}$ & $10.00 \pm 0.02^{\mathrm{ab}}$ & $10.00 \pm 0.04^{\mathrm{ab}}$ & - & $11.00 \pm 0.03^{\mathrm{b}}$ & $09.00 \pm 0.06^{\mathrm{a}}$ & - \\
\hline \multicolumn{8}{|c|}{ Gram-positive bacteria } \\
\hline $\begin{array}{c}\text { Staphylococcus. aureus } \\
\text { ATCC } 13,150\end{array}$ & $14.00 \pm 0.04^{\mathrm{bc}}$ & $11.00 \pm 0.02^{\mathrm{ab}}$ & $13.00 \pm 0.04^{\mathrm{b}}$ & - & - & $10.00 \pm 0.05^{\mathrm{a}}$ & - \\
\hline $\begin{array}{c}\text { Staphylococcus. aureus } \\
\text { ATCC } 12,600\end{array}$ & $11.00 \pm 0.02^{\mathrm{ab}}$ & $11.00 \pm 0.05^{\mathrm{ab}}$ & $10.00 \pm 0.06^{\mathrm{a}}$ & - & $11.00 \pm 0.07^{\mathrm{ab}}$ & - & - \\
\hline $\begin{array}{c}\text { Listeria. monocytogenes } \\
\text { ATCC 19,118 }\end{array}$ & $12.00 \pm 0.02^{b}$ & $12.00 \pm 0.05^{\mathrm{b}}$ & $10.00 \pm 0.05^{\mathrm{a}}$ & - & $13.00 \pm 0.02^{\mathrm{c}}$ & - & - \\
\hline $\begin{array}{c}\text { Bacillus. cereus ATCC } \\
14,579\end{array}$ & $14.00 \pm 0.03^{\mathrm{b}}$ & $12.00 \pm 0.05^{\mathrm{ab}}$ & $11.00 \pm 0.06^{\mathrm{a}}$ & - & $11.00 \pm 0.02^{\mathrm{a}}$ & - & - \\
\hline \multicolumn{8}{|c|}{ Fungi } \\
\hline $\begin{array}{l}\text { Candida. albicans } \\
\text { KCTC } 7965\end{array}$ & $15.00 \pm 0.01^{b}$ & - & $13.00 \pm 0.05^{\mathrm{a}}$ & $14.00 \pm 0.03^{\mathrm{ab}}$ & - & - & - \\
\hline $\begin{array}{l}\text { Aspergillus. fumigatus } \\
\text { КСТC } 6145\end{array}$ & $08.50 \pm 0.02^{\mathrm{a}}$ & - & - & $10.00 \pm 0.05^{\mathrm{b}}$ & - & - & - \\
\hline $\begin{array}{l}\text { Aspergillus. flavus var. } \\
\text { flavus KCTC } 6143\end{array}$ & $10.00 \pm 0.05^{\mathrm{ab}}$ & $10.00 \pm 0.03^{\mathrm{ab}}$ & - & $09.00 \pm 0.03^{\mathrm{a}}$ & - & - & - \\
\hline $\begin{array}{c}\text { Aspergillus. niger } \\
\text { КСТC } 6317\end{array}$ & $09.00 \pm 0.02^{\mathrm{a}}$ & $09.00 \pm 0.01^{\mathrm{a}}$ & $10.00 \pm 0.03^{\mathrm{ab}}$ & $09.00 \pm 0.05^{\mathrm{a}}$ & - & - & - \\
\hline
\end{tabular}

CE: Chloroform extract, TE: Toluene Extract, DE: Dichloromethane Extract, EEE: Ethyl Ether Extract, EtE: Ethanol Extract, ME: Methanol Extract, DWE: Distilled Water Extract. -: no inhibition zone, a-c letters are according to increasing mean values, different letters in each row for each extract's antimicrobial activity represent statistically significant difference $(p<0.05)$, same letters in each row for each extract's antimicrobial activity represents non-significant difference $(p>0.05)$.

\subsubsection{Determination of Minimum Inhibitory Concentration (MIC)}

The MIC of the selected RC extract was quantified according to the method of Bussmann et al. [8] using a 96-well microplate. The MIC was performed for Staphylococcus aureus ATCC 13,150 and Escherichia coli ATCC 35150. Briefly, $0.5 \mathrm{~mL}$ of the sterilized NB broth filled into the 7 wells of each row. Sequentially, an additional $0.5 \mathrm{~mL}$ of a mixture of culture medium $\left(10^{6} \mathrm{CFU} \cdot \mathrm{mL}^{-1}\right)$ and $\mathrm{RC}$ extract serially diluted to make a concentration range from $3.30-33 \mathrm{mg} \cdot \mathrm{mL}^{-1}$ and well 1 served as growth control. The microplate was then incubated at $37^{\circ} \mathrm{C}$ for $24 \mathrm{~h}$ and the resulting turbidity was observed using spectrophotometer at the optical density $\left(\mathrm{OD}_{600} \mathrm{~nm}\right)$. The MIC was defined as the lowest concentration of the RC chloroform extract, which exhibited clear fluid with no evolvement of turbidity.

\subsubsection{Thermal Stability}

The thermal stability of red cabbage chloroform (RCC) extract was evaluated by following the methodology proposed by Rubab et al. [6]. Briefly, the extract was heated at $95^{\circ} \mathrm{C}$ for 5, 45, and $90 \mathrm{~min}$. Thereafter, the antimicrobial potential was estimated by the disc diffusion method as described in Section 2.4.2.

\subsection{Docking Method}

An in silico docking study was applied to investigate the interactions between the compounds, from the cabbage extracts and two target bacterial proteins (lipoprotein; LpxC and bacterial type II topoisomerase inhibitor; NBTI). The crystal structure of bacterial targets proteins such as LpxC (PDB ID: 3U1Y) UDP-3-O-(R-3-hydroxymyristoyl)- $N$-acetylglucosamine deacetylases, and novel bacterial topoisomerases inhibitors (PDB ID: 4PLB) [9] were obtained from the protein data bank (https://www.rcsb.org/). The compound (ligands) structure was prepared using the ACD/ChemSketch based on the canonical SMILES procured from NCBI (https://www.ncbi.nlm.nih.gov/pccompound). Receptor and ligands were pretreated using the standard method as described earlier [10]. Moreover, 
the interacts and docking energy were calculated using the Argus Lab 4.0.1 (Mark Thompson and Planaria Software LLC) and BIOVIA Discovery Studio 2016 (Accelrys Software Inc., San Diego, CA, USA). Further, the results of molecular docking were verified by in vitro antimicrobial experiments for 5-Methylfuran-2-carbaldehyde (hydroquinone; CAS number: 123-31-9), 2-methoxy-4-vinylphenol (CAS number: 7786-61-0), 2-Purinol (hypoxanthine; CAS number: 68-94-0), benzofuran (2,3-benzofuran; CAS number: 271-89-6), 4H-Pyran-4-one (CAS number: 108-97-4), and 2-Furancarboxaldehyde (furfural; CAS number: 98-01-1).

\subsection{Cytotoxicity Assay}

The cytotoxicity of the different extracts on breast cancer cell-line (MCF-7) cells was measured using MTT assay by following the previously reported methodology [6].

\subsection{In Vivo Analysis of Cytotoxicity}

\subsubsection{C. elegans Culture Conditions}

The wild-type (N2) Caenorhabditis elegans strains were obtained from the Caenorhabditis Genetic Center (CGC; MN). Prior to further experiments, worms were cultured and maintained on standard Nematode Growth Media (NGM) medium at $20{ }^{\circ} \mathrm{C}$ with living OP50 E. coli as food source.

\subsubsection{Chemotaxis Assay}

The chemotaxis assay was performed by following the methodology of Chelliah et al. [11], with some modifications. Briefly, $10 \mu \mathrm{L}$ of OP50 were seeded with worms at the L4 stage. The 50 young adult stage worms were transferred to a $5 \mathrm{~cm}$ plate (in center), and movement of worms were monitored using a two-quadrant system. The movement of worms were monitored and counted after $90 \mathrm{~min}$ of incubation at $25{ }^{\circ} \mathrm{C}$. Chemotaxis assay was conducted in triplicate; chemotaxis index $(\mathrm{CI})$ was quantified according to Chelliah et al. [11] and expressed in $\mathrm{CI} \%$, referring to the number of worms in the extract by the total number of worms used.

\subsubsection{Colonization Assay (In Vivo Antimicrobial Activity)}

Colonization assay was conducted according to the methodology of Chelliah et al. [11] with some modifications. Briefly, extract plus OP50 were seeded on NGM plates, having worms, and incubated for 9 days, and the total number of worms counted first at the third day of incubation, and then with an interval of 2 days until the end of incubation period. At each tested day, 5 worms were picked and washed in $5 \mu \mathrm{L}$ drops of Triton $\mathrm{x}-100(1 \%)$ for paralysis, and to hinder pharyngeal pumping and expulsion. The washed worms were transferred to an Eppendorf tube, having $50 \mu \mathrm{L}$ of Triton $\mathrm{x}-100$ $(1 \%)$, and disrupted mechanically using a pestle and mortar. Worm lysates were then serially diluted in phosphate buffered saline, and incubated on Eosin Methylene Blue agar, overnight, at $37^{\circ} \mathrm{C}$. E. coli colonies were counted and enumerated the number of bacteria/nematodes.

\subsection{Application of RCC Extract on Raw Beef Meat}

\subsubsection{Beef Sample Preparation and Storage Conditions}

Fresh boneless beef was procured from a local supermarket, stored immediately in an insulated polystyrene box, and kept at $4{ }^{\circ} \mathrm{C}$ for further analysis. Beef fillets were then aseptically cut to $50 \mathrm{~g}$ piece and divided into three categories. Each category received 5 pieces of beef for subsequent microbial and quality analysis. The samples were assigned to one of three treatments: C: control (no addition), RCC-A: $1.5 \%$, and RCC-B: $2 \%$ red cabbage chloroform (RCC) extract. The treatment was given for $20 \mathrm{~min}$, the respective extract, and then drained for $1 \mathrm{~h}$ in a safety bench. The treated samples and controls were separately packaged in low-density polyethylene bags (Whirl-Pak, Nasco, Fort Atkinson, WI, USA) and stored at $4{ }^{\circ} \mathrm{C}$ for up to 16 days. The beef samples were investigated with 4 days of 
interval for microbial, $\mathrm{pH}$, instrumental color attributes moisture, texture, and thiobarbituric acid reactive substances (TBARS); the above-described experiment was performed in triplicate on days 0,4 , 8,12 , and 16 .

\subsubsection{Microbial Analysis}

The $10 \mathrm{~g}$ of meat samples were homogenized with $90 \mathrm{~mL}$ of sterilized $0.1 \%$ buffered peptone water (BPW) in a sterile stomacher bag for $2.5 \mathrm{~min}$ in a bag mixer (BagMixer, MonotaRO Co., Ltd., Japan). The sample dilutions $(0.1 \mathrm{~mL})$ of appropriate dilution in $0.1 \%$ BPW of beef homogenate were plated on the surface of different selective agars. The plate count agar (PCA) was used for total viable count (TVC), and total psychrotrophic bacteria count (TPC), and incubated at $37^{\circ} \mathrm{C}$ for $48 \mathrm{~h}$ and at $7{ }^{\circ} \mathrm{C}$ for 7 to 10 days, respectively. The Dichloran Rose Bengal Chloramphenicol (DRBC) agar was used for yeast and molds, and incubated at $25{ }^{\circ} \mathrm{C}$ for 3 to 5 days. The microbiological counts were transformed to $\log _{10}$ CFU.g ${ }^{-1}$ of beef meat.

\subsubsection{Physiochemical Analysis}

$\mathrm{pH}$ Analysis

The $\mathrm{pH}$ value was evaluated according to [12]. Briefly, each sample (10 g) was homogenized with $90 \mathrm{~mL}$ distilled water and homogenized for $1 \mathrm{~min}$ in homogenizer (Ultra-Turraz, T25-S1, IKA, Staufen, Germany). The $\mathrm{pH}$ was measured using a pH meter (Mettler Toledo SB 8001; Shanghai Mettler Ltd., China).

\section{Color Measurements}

Color was measured using a MiniScan XE Plus Hunter meter (HunterLab Associates Inc., Reston, VA, USA) right on the beef surface. The color was expressed as $L^{*}$ (lightness), $a^{*}$ (redness), and $b^{*}$ (yellowness).

\section{Texture Profile Analysis (TPA)}

The TPA of the beef sample was conducted using an instrumental texture analyzer (FRTS-50N; IMADA CO., LTD, Japan) by following the methodology of Barekat and Soltanizadeh [13], with slight modifications. The following texture parameters were evaluated: hardness, springiness, gumminess, chewiness, and cohesiveness, by compressing $20 \%$ deformation forces, using a compression load ( $7 \mathrm{~kg})$ with a probe diameter of $30 \mathrm{~mm}$ on meat surface.

\section{Moisture Analysis}

The Association of Official Analytical Chemists (AOAC) method was used to determine the moisture content of beef sample with and without treatment (925.10, [14]). Approximately $5 \mathrm{~g}$ of the beef sample from each treatment with 4 day intervals was weighed aseptically, then the solid content was examined after complete dehydration of the beef sample, using for $20 \mathrm{~min}$ at $140{ }^{\circ} \mathrm{C}$ in moisture analyzer (WBA-110M 0.01-110 g; WITEG LABORTECHNIK GMBH, Germany). The percentage decline in weight was demonstrated as moisture content, the experiment was performed in triplicate, and the average was considered as the moisture content of the product.

Thiobarbituric Acid Reactive Substances (TBARS)

The TBARS values were determined to evaluate the lipid stability of the beef using a modified method based on Du and Ahn [15]. Concisely, $5 \mathrm{~g}$ of beef sample was transferred to a polystyrene bag contained $15 \mathrm{~mL}$ of deionized distilled water (DW) and homogenized for $2 \mathrm{~min}$. Then $1 \mathrm{~mL}$ of beef homogenate was fetched to a test tube having $2 \mathrm{~mL}$ of $15 \mathrm{mM}$ thiobarbituric acid (TBA) and trichloroacetic acid (15\%; TCA). The $50 \mu \mathrm{L}$ of $7.2 \%(\mathrm{w} / \mathrm{v})$ solution of butylated hydroxytoluene (BHT) was added to each test tube and was further vortexed for few seconds. The samples were then placed 
in the boiling water bath for $15 \mathrm{~min}$ to generate color, cooled to room temperature for $10 \mathrm{~min}$, and the absorbance was observed at $531 \mathrm{~nm}$ by employing spectrophotometer against deionized water blank. The TBARS values were derived from a calibration curve (TEP) and demonstrated as $\mu$ mol. $\mathrm{kg}^{-1}$ of the beef sample.

\subsection{Statistical Analysis}

All experiments were conducted in triplicate and expressed as mean \pm standard deviation (SD). The data were analyzed using SAS program (SAS Institute Inc., USA). Comparison between the groups or treatments were conducted using one-way analysis of variance (ANOVA) and Tukey's test. Differences at $p<0.05$ were considered significant.

\section{Results and Discussion}

\subsection{Antimicrobial Activity}

Phytochemical based antimicrobial compounds from plant sources have been renowned to possess broad-spectrum antimicrobial properties [1]. Particularly, two major groups of polyphenols, phenolic compounds and flavonoid compounds, were reported to hinder a wide range of pathogenic microorganisms $[1,5]$. The mechanism of the plant based antimicrobial action on microorganisms is attributed to the inhibition of synthesis of nucleic acid, immobilization of cytoplasmic membrane function, and non-specific reactions in energy metabolism; however, accurate mechanisms remain to be determined [16]. Previously, a number of studies have been reported, phytochemical based antimicrobial compounds; however, red cabbage extract (used in this study) has not yet been evaluated for its effectiveness towards foodborne pathogens and its utilization in a raw meat system, in terms of food safety.

In this study, the antibacterial and antifungal activities of RC from different solvent extracts were investigated towards fungal and bacterial pathogens using the disc diffusion method (Table 1). All extracts could hinder the growth of the microorganisms to different extents; however, RCC extract exhibited a more effective hindrance, with the highest zone of inhibition for S. aureus ATCC 13,150, and E. coli ATCC 35,150, with the diameter of $14.00 \pm 0.04$ and $13.00 \pm 0.02 \mathrm{~mm}$, respectively. Overall, all tested fungal strains were more sensitive to RCC extract when compared to other extracts. The antimicrobial activity exhibited by RCC extract was equivalent to that of the standard antibiotic gentamicin and sodium metabisulfite; however, no inhibitory activity was perceived towards the negative control for any of the test microorganisms (data not shown here). Gentamicin was inhibitorier to most of the bacterial strains tested.

Further, thermostability of the chloroform extract was evaluated using the disc diffusion method. All heat treatments exhibited the antimicrobial activity towards the organisms tested in this study, so we can say that the compound liable for antimicrobial activity may not be protein in nature (Table 2).

Previously, a number of studies have reported the RC extract of plants possessing antimicrobial activity [6,17]. These results showed that the extracting solvents have a defined impact on bioactive postulates. Generally, the extracts exhibiting a big zone of an inhibition zone, in terms of diameter, with low minimum inhibitory concentration, can be acknowledged as a more effective bioactive agent than that of a small zone of inhibition and high MIC [18]. A micro-dilution assay was conducted to evaluate the susceptibility of the $S$. aureus and E. coli against RCC extract and the results are expressed as MICs. The RCC displayed the MIC values of $16.5 \mathrm{mg} \cdot \mathrm{mL}^{-1}$ against $S$. aureus and E. coli. In the current study, RCC extract was the most effective extract that presented broad-range antimicrobial ability, hinder growth, of all microorganisms tested in this study. 
Table 2. Thermostability of the chloroform extract of RC.

\begin{tabular}{|c|c|c|c|}
\hline \multirow{2}{*}{ List of Microorganisms } & \multicolumn{3}{|c|}{ Heating at $95{ }^{\circ} \mathrm{C}$ for Different Times (min); Zone of Inhibition ( $\mathrm{mm}$ ) } \\
\hline & 5 & 45 & 90 \\
\hline \multicolumn{4}{|c|}{ Gram-negative bacteria } \\
\hline $\begin{array}{c}\text { S. enterica typhimurium } \\
\text { ATCC } 14,028\end{array}$ & $10.00 \pm 0.02^{\mathrm{a}}$ & $13.00 \pm 0.01^{b}$ & $15.00 \pm 0.03^{c}$ \\
\hline E. coli ATCC 35,150 & $09.00 \pm 0.01^{\mathrm{a}}$ & $12.00 \pm 0.02^{\mathrm{b}}$ & $09.00 \pm 0.01^{\mathrm{a}}$ \\
\hline E. coli ATCC 43,894 & $10.00 \pm 0.02^{\mathrm{a}}$ & $10.00 \pm 0.02^{\mathrm{a}}$ & $12.00 \pm 0.03^{\mathrm{b}}$ \\
\hline \multicolumn{4}{|c|}{ Gram-positive bacteria } \\
\hline S. aureus ATCC 13,150 & $10.00 \pm 0.02^{\mathrm{a}}$ & $14.50 \pm 0.01^{\mathrm{b}}$ & $15.50 \pm 0.03^{b c}$ \\
\hline S. aureus ATCC 12,600 & $10.00 \pm 0.02^{\mathrm{a}}$ & $12.00 \pm 0.02^{\mathrm{b}}$ & $12.00 \pm 0.03^{\mathrm{b}}$ \\
\hline $\begin{array}{l}\text { L. monocytogenes } \\
\text { ATCC 19,118 }\end{array}$ & $11.00 \pm 0.03^{\mathrm{a}}$ & $15.00 \pm 0.02^{\mathrm{b}}$ & $16.30 \pm 0.05^{\mathrm{c}}$ \\
\hline B. cereus ATCC 14,579 & $12.00 \pm 0.04^{\mathrm{a}}$ & $15.00 \pm 0.02^{\mathrm{b}}$ & $20.00 \pm 0.03^{c}$ \\
\hline \multicolumn{4}{|c|}{ Fungi } \\
\hline C. albicans КСТС 7965 & $08.00 \pm 0.02^{\mathrm{a}}$ & $10.50 \pm 0.03^{b}$ & $14.00 \pm 0.01^{\mathrm{c}}$ \\
\hline A. fumigatus КСТC 6145 & $08.50 \pm 0.01^{\mathrm{a}}$ & $11.00 \pm 0.05^{\mathrm{b}}$ & $11.00 \pm 0.03^{b}$ \\
\hline $\begin{array}{l}\text { A. flavus var. flavus } \\
\text { KCTC } 6143\end{array}$ & $10.00 \pm 0.03^{\mathrm{a}}$ & $11.30 \pm 0.02^{\mathrm{b}}$ & $13.00 \pm 0.01^{\mathrm{c}}$ \\
\hline A. niger КСТС 6317 & $09.00 \pm 0.01^{\mathrm{a}}$ & $10.00 \pm 0.04^{\mathrm{ab}}$ & $12.30 \pm 0.03^{c}$ \\
\hline
\end{tabular}

-: no inhibition zone, a-c letters are according to increasing mean values, different letters in each row for each extract's antimicrobial activity represent statistically significant difference $(p<0.05)$, same letters in each row for each extract's antimicrobial activity represents non-significant difference $(p>0.05)$.

\subsection{Phenolic and Flavonoid Content}

Preliminary phytochemical screening of different solvent extracts of red cabbage revealed the presence of flavonoids, alkaloids, saponins, and tannins (Table S1). Phenolic and flavonoid compounds are substantial plant components due to their biological activities and scavenging ability because of their hydroxyl group [19]. The crude RCC extract exhibited the highest TP content $\left(85.48 \pm 1.60 \mathrm{mg} \mathrm{GAE}^{-1}\right)$,

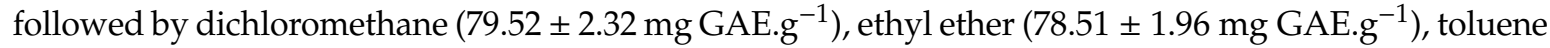

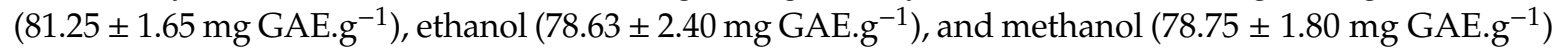
extracts, with a significant differences between them $(p<0.05)$. Phenols are a group of renowned natural antioxidants, comprising hydrolyzable and non-hydrolyzable tannins, flavonoids, lignins, and terpenoids [20,21]. Among all extracts, the highest level of the TFC was recorded for chloroform $\left(28.70 \pm 3.12 \mathrm{mg}\right.$ QE.g $\left.^{-1}\right)$, followed by dichloromethane $\left(26.50 \pm 2.40 \mathrm{mg} \mathrm{QE.g}{ }^{-1}\right)$, ethyl ether $\left(23.01 \pm 1.70 \mathrm{mg} \mathrm{QE.g}{ }^{-1}\right)$, toluene $\left(21.85 \pm 1.90 \mathrm{mg} \mathrm{QE.g}{ }^{-1}\right)$, ethanol $\left(18.20 \pm 2.60 \mathrm{mg} \mathrm{QE.g}{ }^{-1}\right)$, and methanol $\left(15.20 \pm 2.45 \mathrm{mg} \mathrm{QE.g}{ }^{-1}\right)$ extracts. The variation in the concentration of phenolic compounds indicated in literature depends on the choice of solvent. The results indicated that the solvent extract significantly impacted the extraction capacity of the phenolic compounds, in terms of solubility of the polyphenols in the solvent employed for the extraction process [22]. Our results are consistent with previous studies, exhibiting that chloroform is one of the best solvents to extract a wide range of phenolic components from plants.

\subsection{Antioxidant Activity}

Two extensively used antioxidant assays (ABTS and DPPH assay) were employed to evaluate the antioxidant efficiency. Different extracts were quantified by their scavenge on DPPH and ABTS radicals, and ascorbic acid utilized as positive control (Fig.0ure 1). All tested extracts exhibited the DPPH radical activities, ranging from $12 \%-56 \%$, and ABTS radical activities, ranging from $15 \%-61 \%$. In general, the chloroform fraction exhibited the strongest antioxidant activity and, subsequently, toluene and dichloromethane. As exhibited in Figure 1, DPPH and ABTS radical scavenging values were found to be in the order of chloroform extract $<$ toluene extract $<$ dichloromethane extract $<$ ethyl ether extract. Moreover, the DPPH scavenging activity of the RC extract was equivalent to 
those of natural antioxidants $\left(66 \%-78 \%\right.$ at the concentrations of $\left.0.05-0.1 \mathrm{mg} \cdot \mathrm{mL}^{-1}\right)$ acquired from fruits, and vegetables [23]. However, all assayed fractions exhibited inferior activities than that of the control (vitamin C), with $93.7 \%$. The scavenging ability may act as a pronounced index, and Hintz et al. [5] described that the antioxidant activity of destined plant extracts have been coordinated to their reducing powers. The number of phenolic and flavonoid compounds have positive coordination with DPPH and ABTS radical scavenging activities because of hydrogen and electron contribution from hydroxyl groups of these compounds. In general, ABTS assay is considered as potentially more efficient than DPPH assay, since ABTS can estimate both hydrophilic and hydrophobic substances [24]. Among the seven extracts, RCC extract exhibited the magnificent antioxidant activities in both of the antioxidant assays; thus, GC-MS analysis was performed to acquire its component knowledge.

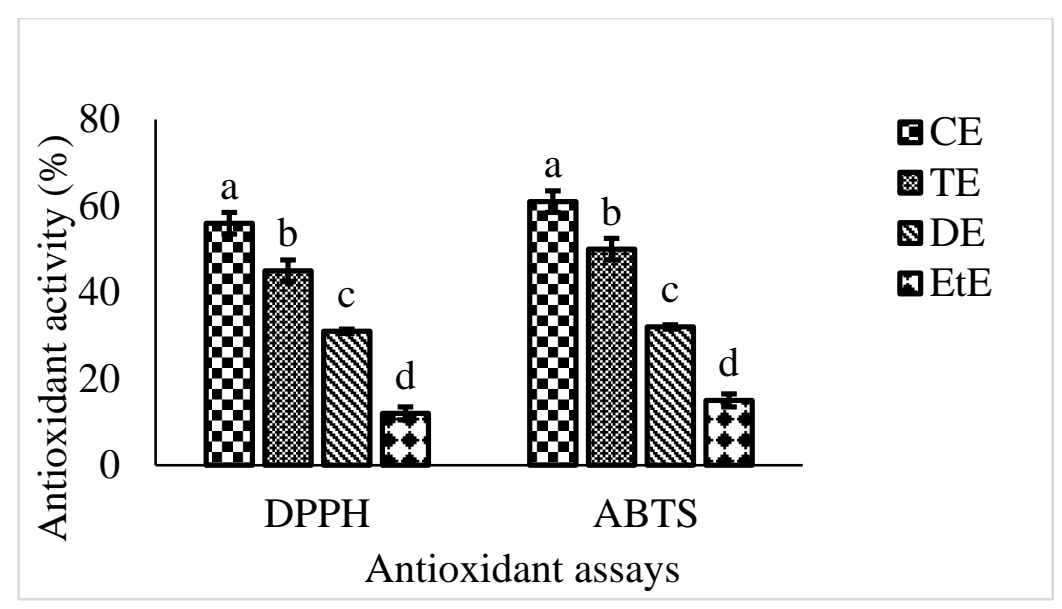

Figure 1. Antioxidant activity of different extracts of RC. CE: Chloroform extract, TE: Toluene extract, DE: Dichloromethane extract, and ETE: Ethyl ether extract. Letters a-d indicates the significance difference among different extracts of RC.

\subsection{GC-MS Analysis}

GC-MS is a productive technique in differentiation, recognition, and quantification of intricate mixtures (such as plant extraction) and confer the most sensitive recognition of bioactive compounds [25]. Thus, GC-MS was conducted to explore the volatile components of the RCC, which exhibited strong antioxidant and antimicrobial activity in RC extract. The GC-MS analysis of RCC resulted in the identification of seven compounds (Table 3) and chromatogram are presented in Figure S1. The analysis showing the existence of phenols, aldehydes, and several organosulfur compounds, in which 2-furancarboxyaldehyde was rarely reported in RCC.

The RCC extract showed major compounds, i.e., 2-furancarboxaldehyde, 5-methylfuran-2carbaldehyde, and 2-methoxy-4-vinylphenol, which may be responsible for antimicrobial activity. According to the GC-MS results, the organosulfur compounds found in RCC extract have been shown to influence multiple biological effects, such as antioxidant, anti-inflammatory, and fungicides, as well as various pharmacological and therapeutic effects [1,5]. The spectrum of these sulfur-containing compounds relies substantially on the extraction methods of the $\mathrm{RC}$, moreover, on the solvent conditions of processing [17]. 
Table 3. Docking results of identified compounds from RCC extract.

\begin{tabular}{|c|c|c|c|c|c|c|c|}
\hline \multirow{2}{*}{ Compound } & \multirow{2}{*}{ Chemical Formula } & \multirow{2}{*}{ Area $(\%)$} & \multirow{2}{*}{$\begin{array}{l}\text { Molecular Weight } \\
\quad\left(\text { g.mol }{ }^{-1} \text { ) }\right.\end{array}$} & \multicolumn{2}{|c|}{ Docking Score (Kcal.mol $\left.{ }^{-1}\right)$} & \multirow{2}{*}{ Activity } & \multirow{2}{*}{ References } \\
\hline & & & & 4PLB & LpxC & & \\
\hline Methylsulfonylmethane & $\mathrm{C}_{2} \mathrm{H}_{6} \mathrm{O}_{2} \mathrm{~S}$ & 0.04 & 94.133 & -6.10 & -6.32 & Antioxidant, anti-inflammatory, anti-cancer & [26] \\
\hline 2-Furancarboxaldehyde & $\mathrm{C}_{5} \mathrm{H}_{4} \mathrm{O}_{2}$ & 0.11 & 96.084 & -5.84 & -5.70 & Antibacterial & {$[27,28]$} \\
\hline 5-Methylfuran-2-carbaldehyde & $\mathrm{C}_{6} \mathrm{H}_{6} \mathrm{O}_{2}$ & 0.05 & 110.111 & -6.94 & -6.96 & Pharmaceutical properties, organic inhibitor & [29] \\
\hline 4H-Pyran-4-one & $\mathrm{C}_{5} \mathrm{H}_{4} \mathrm{O}_{2}$ & 0.06 & 96.084 & -5.40 & -5.91 & Pharmacological activity, & [28] \\
\hline Benzofuran & $\mathrm{C}_{8} \mathrm{H}_{6} \mathrm{O}$ & 0.01 & 118.133 & -8.229 & -8.11 & Anti-inflammatory analgesic, antimicrobial & [30] \\
\hline 2-Purinol & $\mathrm{C}_{5} \mathrm{H}_{4} \mathrm{~N}_{4} \mathrm{O}$ & 0.04 & 136.111 & -6.14 & -6.04 & $\begin{array}{l}\text { Antioxidant, potential of novel } \\
\text { pharmaceuticals; anti-proliferative }\end{array}$ & [31] \\
\hline 2-Methoxy-4-vinyphenol & $\mathrm{C}_{9} \mathrm{H}_{10} \mathrm{O}_{2}$ & 0.01 & 150.174 & -7.70 & -8.63 & $\begin{array}{l}\text { Antimicrobial, antioxidant, anti-inflammatory, } \\
\text { analgesic, anti-germination }\end{array}$ & [30] \\
\hline
\end{tabular}


The antimicrobial potential of the recognized commercially accessible compound was analyzed using the disc diffusion method as depicted in Table S3. Methylsulfonylmethane, 5-methylfuran-2carbaldehyde, 2 purinol, and 4H-Pyran-4-one were not effective at all towards the tested microorganisms, even at higher concentration with $1 \mathrm{mg} \cdot \mathrm{mL}^{-1}$. The 2-methoxy-4-vinylphenol and benzofuran exhibited the strong antibacterial activity and 2-Furancarboxaldehyde exhibited weak antibacterial activity; however, all compounds were not effective towards the tested fungal strains. The antibacterial activity of 2-methoxy-4-vinylphenol and benzofuran were less sensitive towards the tested microorganisms as compared to RCC extract at lower concentration of $0.5 \mathrm{mg} \cdot \mathrm{mL}^{-1}$; however, at a higher concentration of $1 \mathrm{mg} \cdot \mathrm{mL}^{-1}$, it exhibited comparable antibacterial activity, in terms of zone of inhibition (Table S3).

\subsection{In Silico Molecular Docking Mechanism}

The molecular interactions results indicated that among the tested compounds, benzofuran and 2-Methoxy-4-vinylphenol showed the higher negative docking score against 4PLB (-8.229 Kcal.mol $\left.{ }^{-1}\right)$ and LpxC (-8.63 Kcal.mol $\left.{ }^{-1}\right)$, respectively (Table 3). LpxC, an emerging target in Gram-negative bacteria, leads to the synthesis of Lipid A biosynthetic pathway, which is an essential component for the survival of bacteria [9]. In addition, it makes it resistant to commonly used antibiotics [26]. The NBTI is another emerging target, which mediates breakdown of double-stranded DNA and participates in DNA replication and decatenation reactions [27]. In addition, NBTIs have proven to be resistant against fluoroquinolone antibiotics [28]. Therefore, the Benzofuran and 4PLB established the strong interactions with the hydrophobic side chain aliphatic (Ile1131), aromatic (Tyr1101), and unique amino acids Pro 1102 (Figure 2c,d). In case of the 2-Methoxy-4-vinylphenol, LpxC established interaction with the conventional hydrogen bond hydrophobic aliphatic side chain (Ile 336, Ala351, Leu379) and aromatic side chain Tyr546 (Figure 2a,b). The identified compounds have been previously reported in a number of studies as depicted in Table 3. The 2-methoxy-4-vinylphenol have been previously reported in a number of studies due to their wide range of biological activities, such as antimicrobial, antioxidant, anti-inflammatory, analgesic, and anti-germination [29]. With respect to benzofuran, benzofuran and its derivatives are well known for their biological activities, and have potential as emerging natural antimicrobial agents in the food industry [29]. In addition, 2-Furancarboxaldehyde has been identified in a number of studies; however, antimicrobial activity is not pronounced [30]. However, other identified compounds have also been reported in a number of studies due to their antioxidant and anti-inflammatory activity, not well-established for their antimicrobial activity [30,31]. Based on their antimicrobial activity, and previously reported studies, we conclude that 2-methoxy-4-vinylphenol are potential compounds for the antimicrobial activity of RCC extract. Further, we analyze the potential of RCC extract in food (beef) as an antimicrobial agent to enhance the shelf life of meat and meat products.

Additionally, we perform cytotoxicity for its safety aspects, to determine the feasibility of developing an effective and safe antimicrobial agent for a natural preservative. The C. elegans model was used to determine the cytotoxic effect to avoid possible unwanted biological side effects, such as chemotaxis assay (Figure 3 and Table 4).

Table 4. Cytotoxic properties of different extracts of RC in MCF-7 cell line.

\begin{tabular}{ccc}
\hline Sr. No & Plant Extract & IC $_{\mathbf{5 0}}\left(\boldsymbol{\mu} \mathbf{g} \cdot \mathbf{m L}^{-\mathbf{1}}\right) \mathbf{M C F}-\mathbf{7}$ \\
\hline 1 & RC-Chloroform Extract & $>50$ \\
2 & RC-Dichloromethane Extract & $>50$ \\
3 & RC-Toluene Extract & $>50$ \\
4 & RC-Ethyl ether Extract & $>50$ \\
5 & RC-Ethanol Extract & $>50$ \\
6 & RC-Methanol Extract & $>50$ \\
7 & Tamoxifen & 10.08
\end{tabular}

IC: Half-maximal inhibitory concentration, MCF: Michigan Cancer Foundation-7 (breast cancer cell line). 

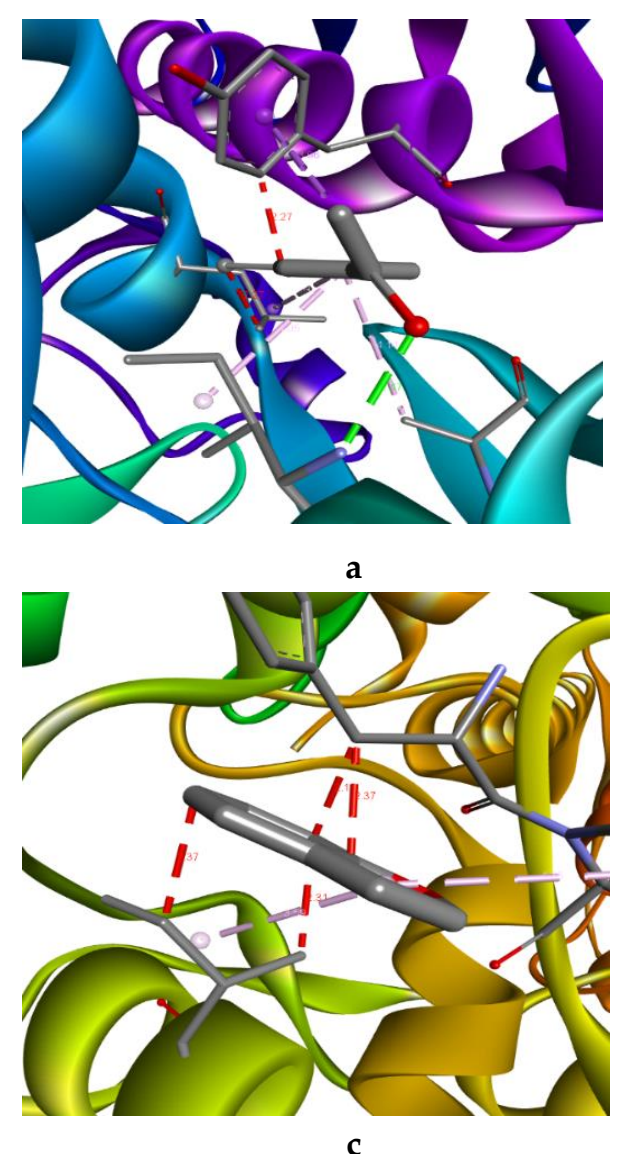

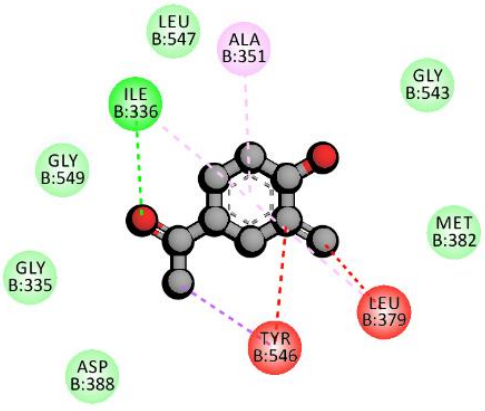

b

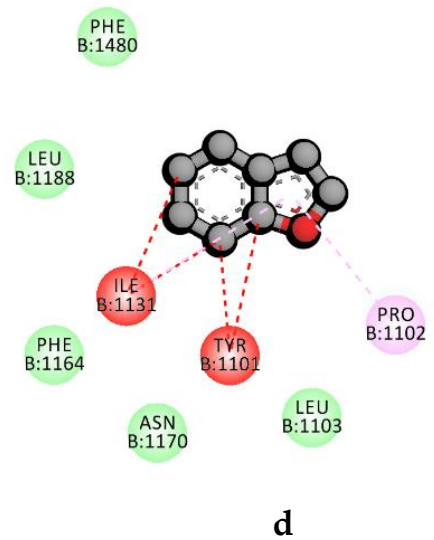

Figure 2. Docking analysis; (a,b). Three-dimensional (3D) and two-dimensional (2D) structures of the interactions between 2-Methoxy-4-vinylphenol and LpxC, respectively, and (c,d). The 3D and 2D structures of the interactions between benzofuran and $4 \mathrm{PLB}$, respectively.

\subsection{Effect of RCC on C. Elegans (In Vivo) Model against E. coli O157:H7}

The effect of RCC extract on C. elegans chemotaxis assay results exhibited in Figure 3 . The C. elegans fed with OP50 showed the highest chemotaxis index, which demonstrates that most of the worms attracted towards OP50 and RCC extract, combined with OP50, showed the comparable chemotaxis index. Less attraction of the worms for the RCC extract, combined with OP50, could be attributed to the benzene carboxylic acid group, which is one of the secondary metabolites present in Brassica vegetables [5]. Among the identified compounds, benzofuran and 2-methoxy-4-vinyphenol combined with OP50 showed a comparable chemotaxis index to OP50. As we discussed in Sections 3.4 and 3.5, benzofuran and 2-methoxy-4-vinyphenol are potential compounds responsible for the antimicrobial activity of RCC extract.

The results of the colonization assay depicted in Figure 3E,F. The L4 stage of the worms failed to lay eggs compared to L1, L3, or L4 stages of worms when fed with OP50 (4.3 log CFU/5 worm), despite the fact that RCC extract combined with OP50 also acts as a substantial food source for worms, and similar results observed by commercially available identified compounds (Figure 3F). However, the results suggest that RCC extract exhibited protective and longevity effects on worms by reducing the E. coli O157:H7 population in the gut of the worm fed with E. coli O157:H7. This beneficial effect of RCC extract may be due to the presence of secondary plant metabolites [5], while worms fed with E. coli O157:H7 leads to an increase in colonization (4.2 log CFU/5 worm).

These results strongly suggest that RC extract contains promising phytochemical compounds that might be beneficial as a natural antimicrobial agent. Remarkably, the effect of RCC extract has not been previously confirmed with the C. elegans model system. 
(A)
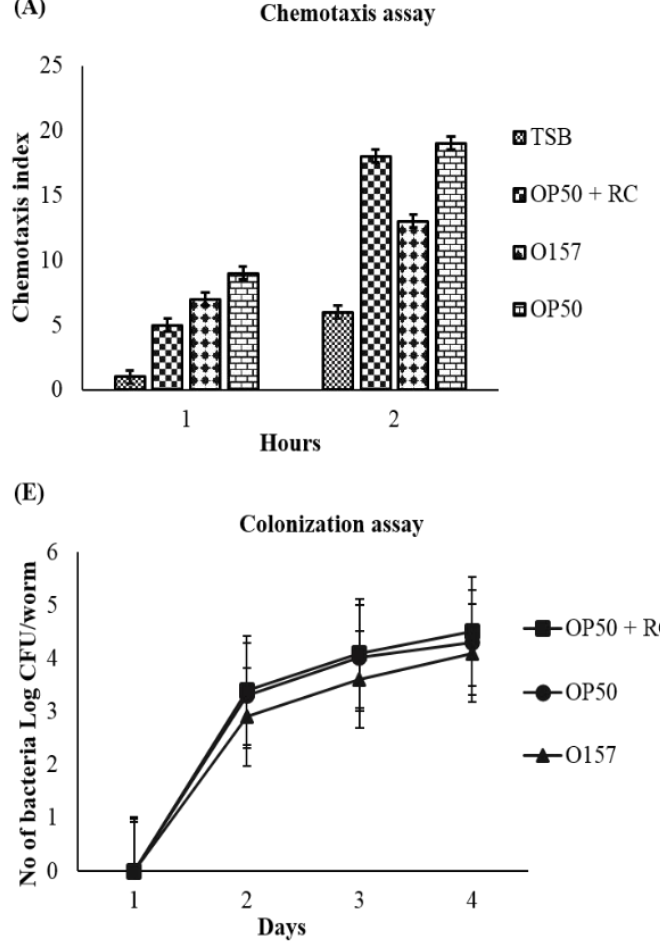

(B)

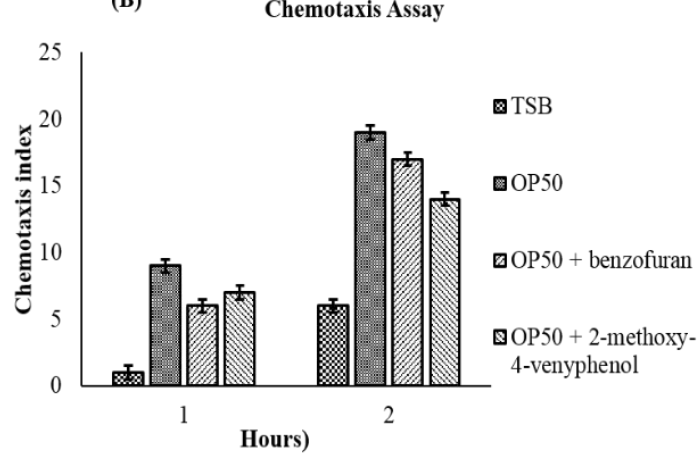

Colonization assay

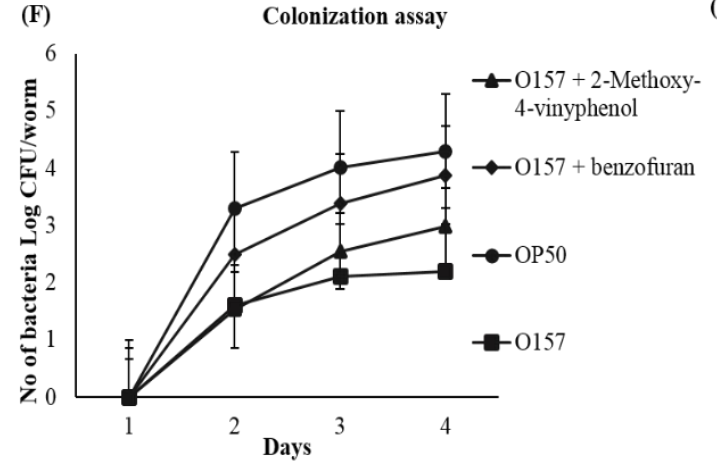

(C)
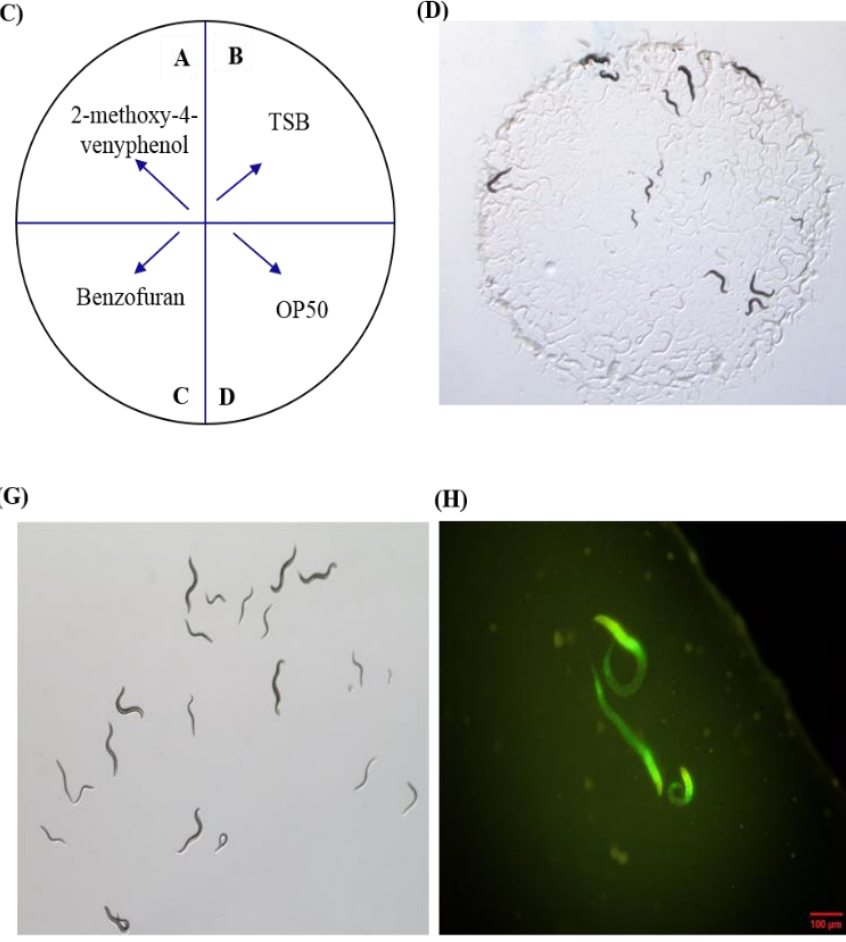

Figure 3. (A) Chemotaxis assay of RC extract compared between E. coli 0157 and E. coli OP50 (basic food for worms), (B) chemotaxis assay compared between OP50 and commercially available identified compounds; 2-methoxy-4-vinyphenol and benzofuran combined with OP50, respectively. (C) The model chart of chemotaxis assay. (D) Chemotaxis assay plate indicates the from the center of the plate worm move towards the test sample equally when compared with control (OP50). (E) Colonization assay indicates the durability of the work when fed [Pathogen-E. coli O157, and Plant extract (RCC extract)]. (F) Colonization assay indicates the durability of the work when fed [Post treatment of 2-methoxy-4-vinyphenol against pathogen-E. coli O157 + benzofuran against pathogen-E. coli O157 $+2,3$ and E. coli 0157 (pathogen)]. (G) Stereomicroscopic image on the Morphology of C. elegans after the colonization assay. (H) The stereomicroscopic image indicates the green spots (Syto-9) healthy live cells of the C. elegans after the colonization assay. 


\subsection{Shelf Life Study}

\subsubsection{Changes in Microbial Profile}

Changes in TVC, psychrotrophic and yeast, and molds of beef samples are shown in Figure 4a-c. The results exhibit that the microbial population decreased with the addition of the natural extract, and showed longer storage. Among the experimental categories, control sample showed the swift increase in the number of microorganisms, followed by the samples treated with RCC-B and RCC-A. The addition of RCC extract derived in depletion in growth rate of TVC. The TVC was, initially, approximately 3.54, 3.51, and 3.53 CFU. ${ }^{-1}$ for control, RCC-A and RCC-B, respectively (Figure 4a), which is consistent with the results of the fresh beef treated with chitosan [12]. By the end of the fourth day, the TVC of RCC-B treatment was significantly lower $(p<0.05)$ as compared to RCC-A and the control. TVC increased with respect to increase in storage period, and increased up to $6.9 \log \mathrm{CFU} \cdot \mathrm{g}^{-1}$ at day 8 for control, and at day 12 for RCC-A, which was evaluated as higher acceptability for fresh meat [32].

Psychrotrophic bacteria can comprise an important fraction of the natural microflora of beef products, which may cause spoilage of meat at $4{ }^{\circ} \mathrm{C}$ storage [32]. The initial psychrotrophic bacterial counts were found to be $3.68 \log \mathrm{CFU} . \mathrm{g}^{-1}$ meat for all categories $(p<0.05)$. At the end of storage period, the highest psychrotrophic bacterial count was obtained for control $\left(9.11 \log \mathrm{CFU} . \mathrm{g}^{-1}\right)$, followed by RCC-A (8.41 log CFU.g ${ }^{-1}$ ) and RCC-B (7.85 log CFU.g ${ }^{-1}$ ) (Figure 4b).

Yeast and molds were found to be another important part of natural microflora of beef, which are responsible for the spoilage of meat [32]. The initial yeast and mold counts were found to be 3.93, 3.91, and $3.90 \log$ CFU.g ${ }^{-1}$ for control, RCC-A and RCC-B categories, respectively. Yeast and mold counts increased with the storage period, and reached to $9.17 \mathrm{log}$ CFU.g ${ }^{-1}$ for control, followed by RCC-A and RCC-B with 8.37 and $7.97 \log$ CFU.g ${ }^{-1}$, respectively, at the end of storage period (Figure 4c). Taken together, the pronounced increase in the count of all groups of microorganisms was noted in the C sample, substantially for TVC and psychrotrophic bacteria.

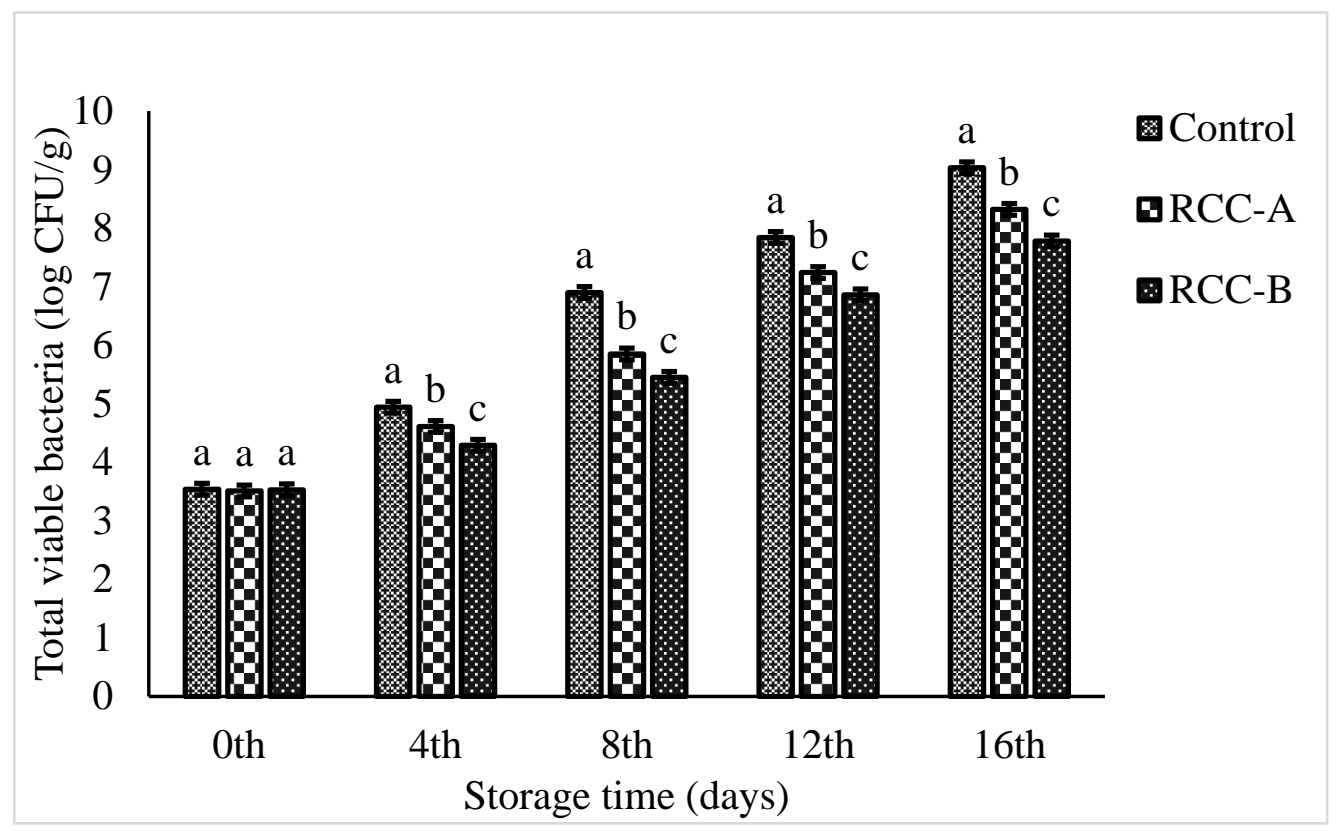

(a)

Figure 4. Cont. 


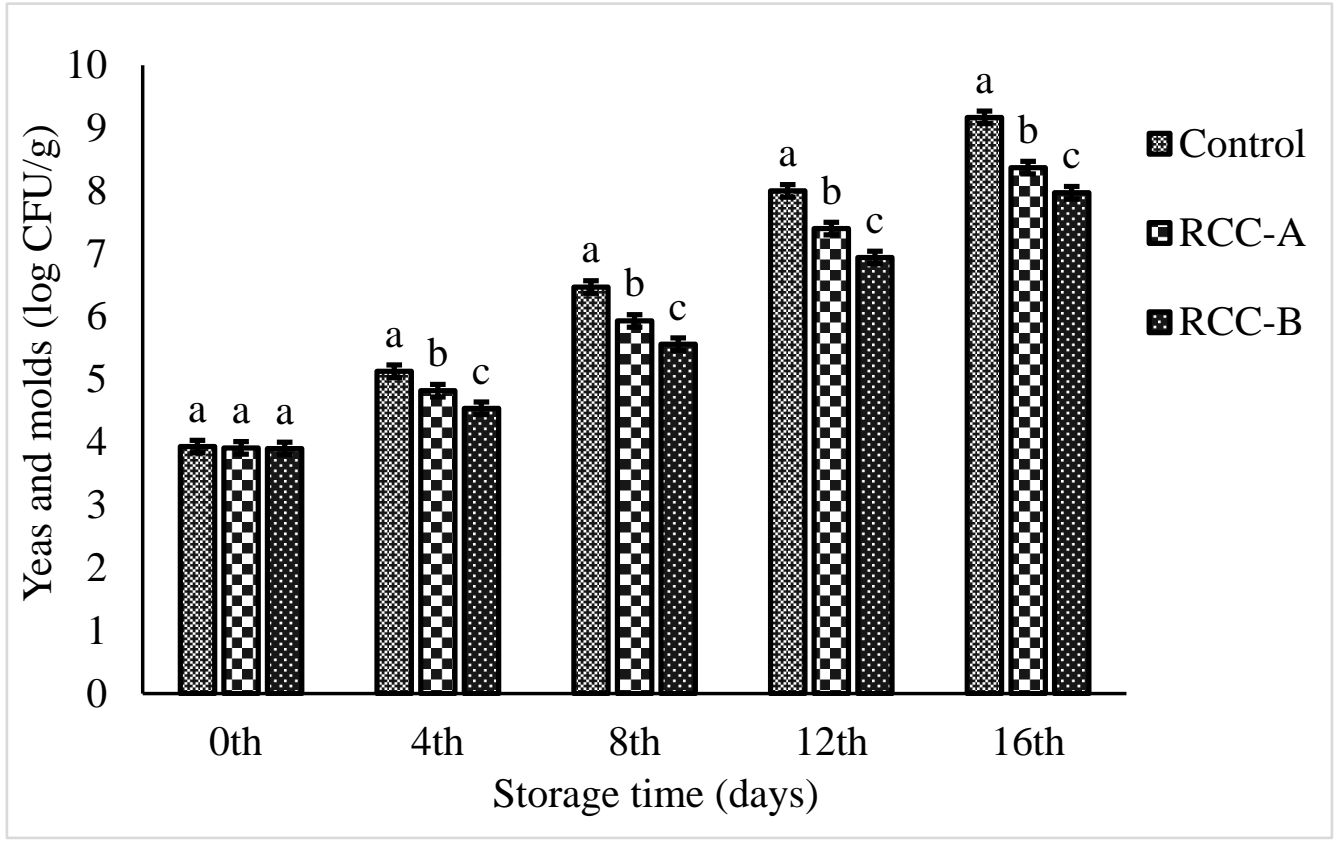

(b)

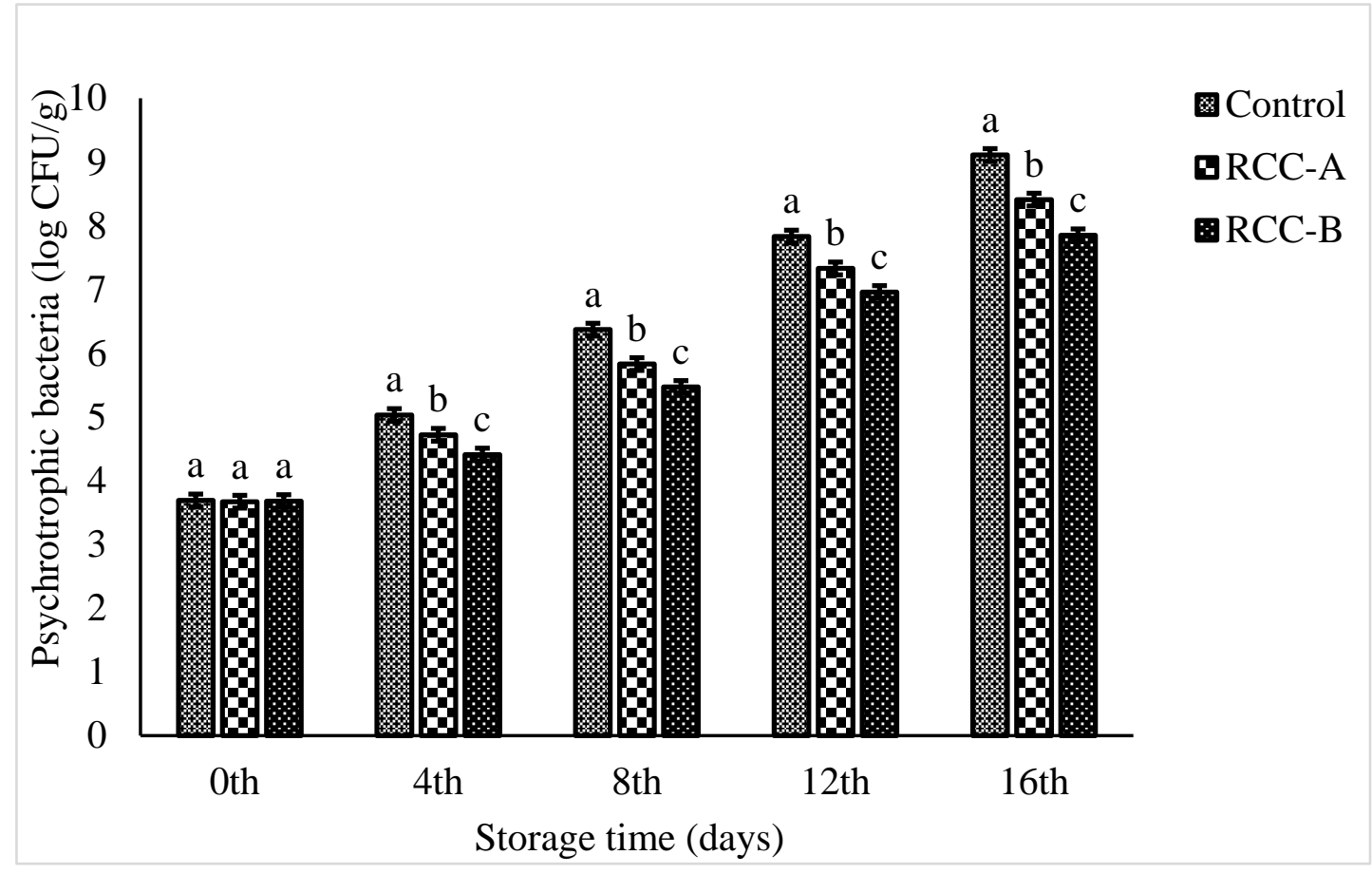

(c)

Figure 4. Effect of white cabbage extract A and B on (a) total viable count, (b) yeast and molds, and (c) psychrotrophic bacteria in beef meat during storage at $4{ }^{\circ} \mathrm{C}$. Values representing mean $\pm \mathrm{SD}$ of three replicates; different letters indicate significant difference $(p<0.05)$ for each time; same letters indicate no significant difference $(p>0.05)$ for each time.

Natural plant extracts exhibited antimicrobial activity towards all test microorganisms. Several other studies suggest that shelf life of meat and meat products can be extended by compounds from plant 
extracts and essential oils or a combination of both [1,33-35]. To the best of our knowledge, the impact of RCC extracts on the microbiological stability of meat and meat products had not been investigated priorly. Fernández et al. [36] had denoted that 5\% citrus extract treatment entirely restricted the growth of lactic acid bacteria (LAB) in beef meat balls during a 12-day storage period. In another study, lamb meat treated with rosemary extracts $(10 \%$ and $20 \%$ ) had lower extent of TVC during 21 days of storage in modified atmosphere packaging $\left(70 \% \mathrm{O}_{2}, 30 \% \mathrm{CO}_{2}\right)$; however, no substantially significant differences were recorded among the variants [37]. Therefore, the microbial counts of all analyzed microorganisms were lower in beef samples treated with RCC extract; they could be used for delaying microbial growth and extending the shelf life of meat and meat products.

\subsubsection{Changes in $\mathrm{pH}$}

The effect of RCC extract on the $\mathrm{pH}$ of beef at $4{ }^{\circ} \mathrm{C}$ storage is depicted in Table 5 . The initial $\mathrm{pH}$ of the $C$ samples was $5.64 \pm 0.02$, which is consistent with reports by other authors [12]. During storage, the $\mathrm{pH}$ values of $\mathrm{C}$ and extract treated samples depleted slightly on the fourth day, and then gradually increased by the end of storage (Table 5); our results are consistent with the previous results [38]. Such a rise in the $\mathrm{pH}$ of control samples indicate the degree of meat spoilage, because of microbial or protein breakdown for the elevation of free amino acids guided to the generation of $\mathrm{NH}_{3}$, amines, and compounds of alkaline reaction, which ultimately cause an increase in $\mathrm{pH}$ [39]. During storage period, control samples displayed a significantly higher $\mathrm{pH}$ value than the treated samples, which is compatible with reports by other authors [12,38]. The $\mathrm{pH}$ of RCC-A and RCC-B were sustained throughout the storage period and no big change was perceived, which may be due to the presence of phenolic compounds (2-Methoxy-4-vinyphenol, 2-Purinol, and methysulfonylmethane). In addition, these compounds have previously been reported from other plant sources for their strong antioxidant activity $[31,40]$.

Table 5. The effect of RCC extract on the $\mathrm{pH}$, thiobarbituric acid reactive substances (TBARS), and moisture values of beef during storage at $4{ }^{\circ} \mathrm{C}$.

\begin{tabular}{ccccccc}
\hline \multirow{2}{*}{$\begin{array}{c}\text { Quality } \\
\text { Attributes }\end{array}$} & \multicolumn{5}{c}{ Storage Time (days) at $\mathbf{4}^{\circ} \mathbf{C}$} \\
\cline { 2 - 6 } & Treatments & $\mathbf{0}$ & $\mathbf{4}$ & $\mathbf{8}$ & $\mathbf{1 2}$ & $\mathbf{1 6}$ \\
\hline pH & Control & $5.64 \pm 0.02^{\mathrm{a}}$ & $5.37 \pm 0.01^{\mathrm{a}}$ & $6.29 \pm 0.01^{\mathrm{a}, \mathrm{b}}$ & $6.61 \pm 0.01^{\mathrm{b}}$ & $6.89 \pm 0.03^{\mathrm{b}}$ \\
& RCC-A & $5.63 \pm 0.01^{\mathrm{a}}$ & $5.31 \pm 0.05^{\mathrm{a}}$ & $5.69 \pm 0.05^{\mathrm{a}}$ & $5.61 \pm 0.05^{\mathrm{a}}$ & $5.73 \pm 0.03^{\mathrm{a}}$ \\
& RCC-B & $5.61 \pm 0.01^{\mathrm{a}}$ & $5.23 \pm 0.08^{\mathrm{a}}$ & $5.51 \pm 0.08^{\mathrm{a}}$ & $5.53 \pm 0.01^{\mathrm{a}}$ & $5.62 \pm 0.05^{\mathrm{a}}$ \\
TBARS (mg & Control & $0.29 \pm 0.01^{\mathrm{a}}$ & $0.99 \pm 0.01^{\mathrm{a}, \mathrm{b}}$ & $1.45 \pm 0.01^{\mathrm{a}, \mathrm{b}}$ & $1.84 \pm 0.08^{\mathrm{a}}$ & $2.73 \pm 0.04^{\mathrm{b}}$ \\
MDA/kg) & RCC-A & $0.25 \pm 0.05^{\mathrm{a}}$ & $0.55 \pm 0.01^{\mathrm{a}}$ & $0.98 \pm 0.01^{\mathrm{a}}$ & $1.51 \pm 0.01^{\mathrm{a}}$ & $2.05 \pm 0.03^{\mathrm{a}}$ \\
& RCC-B & $0.26 \pm 0.06^{\mathrm{a}}$ & $0.46 \pm 0.09^{\mathrm{a}}$ & $0.89 \pm 0.01^{\mathrm{a}}$ & $1.42 \pm 0.08^{\mathrm{a}}$ & $1.62 \pm 0.05^{\mathrm{a}}$ \\
Moisture (\%) & Control & $43.28 \pm 0.03^{\mathrm{a}}$ & $41.07 \pm 0.02^{\mathrm{b}}$ & $38.40 \pm 0.02^{\mathrm{a}}$ & $36.05 \pm 0.06^{\mathrm{a}, \mathrm{b}}$ & $32.16 \pm 0.08^{\mathrm{a}}$ \\
& RCC-A & $43.17 \pm 0.05^{\mathrm{a}}$ & $40.79 \pm 0.01^{\mathrm{a}}$ & $39.14 \pm 0.02^{\mathrm{a}, \mathrm{b}}$ & $35.57 \pm 0.07^{\mathrm{a}}$ & $32.33 \pm 0.05^{\mathrm{a}}$ \\
& RCC-B & $43.31 \pm 0.06^{\mathrm{a}}$ & $41.06 \pm 0.04^{\mathrm{b}}$ & $40.05 \pm 0.03^{\mathrm{b}}$ & $37.21 \pm 0.05^{\mathrm{b}}$ & $34.04 \pm 0.07^{\mathrm{b}}$ \\
\hline
\end{tabular}

All values are expressed as mean \pm SD of three replicates; $a$ and b letters are according to increasing mean values; different letters in each column for each quality analysis represent statistically significant difference $(p<0.05)$; same letters in each column for each quality analysis represents non-significant difference $(p>0.05)$.

\subsubsection{Changes in Moisture}

The moisture content is a recurring parameter in food storage and preservation, and fresh meat typically contains higher moisture content (approximately 70\%-75\%). Alteration in moisture content may induce significant variations in the stability and quality of food. The lowest value of the moisture displayed the low sensitivity of meat to microbial growth. Overall, moisture content, cautiously, moderately depleted in all of the meat samples, including both $\mathrm{C}$ and RCC treated samples at $4{ }^{\circ} \mathrm{C}$ storage (Table 5). Although, the decrease in moisture content $(\%)$ was significantly lower $(p<0.05)$ in RCC-B treated samples when compared to control and RCC-A extract. Generally, irrespective of any type of meat, moisture content gradually decreased at $4{ }^{\circ} \mathrm{C}$ storage. 


\subsubsection{Changes in TBARS}

The effect of RCC polyphenolic extract on lipid oxidation (described as TBARS) at $4{ }^{\circ} \mathrm{C}$ storage is depicted in Table 5. The RCC extract influenced a substantial inhibitory effect on the production of TBARS, however, with diverse intensity. At the beginning of storage (day 0 ), no significant differences were distinguished among treatments and control. The TBARS values for all treated samples varied between $0.25 \pm 0.05$ to $0.51 \pm 0.03 \mathrm{mg}$ MDA. $\mathrm{kg}^{-1}$ meat showing a very low degree of lipid oxidation, however, gradually increased by the end of storage period. After 16 days of storage, TBARS values of RCC-A and RCC-B categories were 2.05 and $1.62 \mathrm{mg} \mathrm{MDA.kg}{ }^{-1}$, respectively, where the control sample was obtained as $2.73 \mathrm{mg}$ MDA. $\mathrm{kg}^{-1}$; our results are consistent with previously reported studies [32]. The RCC leafy extracts significantly $(p<0.05)$ depleted TBARS production compared to the $C$ samples exhibiting an antioxidant effect. The lowest increase of TBARS values were observed in meat samples treated with RCC-B (2\%).

Phytochemical compounds are renowned as effective antioxidants [1]. Hence, it was logical to anticipate that the utilization of natural plant extracts should restrict lipid oxidation and extend the shelf life of meat. The results of current studies identify the potential of RC extract as an effective natural antioxidant to extricate towards lipid oxidation under storage. The utilization of natural plant extracts affect the microbial population in meat products by restricting metabolic activity [5]. In previous studies, it has been reported that TBARS values, equivalent to or greater than $2 \mathrm{mg}$ MDA. $\mathrm{kg}^{-1}$ meat, incorporate the threshold for determining off-odors and 'off-taste' for consumers [39]. Such high TBARS values were not documented in the current study. The values of TBARS in RCC-B treatment were considerably lower than in C and RCC-A treated samples $(p<0.05)$, indicating that the RCC-B treatment constructively protected from lipid oxidation of raw meat.

\subsubsection{Color Analysis}

Color generation and stability were considered as salient markers of the quality of raw meat and meat products. Table 6 depicts the lightness $\left(L^{*}\right)$, redness $\left(a^{*}\right)$, and yellowness $\left(b^{*}\right)$ of meat with and without RCC extract at $4{ }^{\circ} \mathrm{C}$ storage. The highest $a^{*}$ values under storage were perceived for the $\mathrm{C}$ samples. The red color of a meat product is a salient factor aspired by the majority of consumers. If the redness values extend from 4.60 to 10.80, the product is recognized as brown [41]. Unfortunately, the usage of plant extracts did not permit to attain the desired red color. During the first 8 days of storage, only RCC-B treated meat samples were red. The $a^{*}$ values were calculated as 20.12 and 10.63 , respectively. After 8 days, the $a^{*}$ value of the RCC-B sample was substantially higher than that of RCC-A treated samples, but still less than in control samples.

Table 6. Changes in color parameters of beef meat treated with RC extract during storage at $4{ }^{\circ} \mathrm{C}$.

\begin{tabular}{lcccccc}
\hline \multirow{2}{*}{ Treatments } & \multirow{2}{*}{ Parameters } & \multicolumn{5}{c}{ Storage Time (days) at $\mathbf{4}^{\circ} \mathbf{C}$} \\
\cline { 3 - 7 } & & $\mathbf{0}$ & $\mathbf{4}$ & $\mathbf{8}$ & $\mathbf{1 2}$ & $\mathbf{1 6}$ \\
\hline Control & $L^{*}$ & $48.44 \pm 0.08^{\mathrm{a}}$ & $47.42 \pm 0.02^{\mathrm{a}}$ & $44.12 \pm 0.08^{\mathrm{a}}$ & $40.96 \pm 0.06^{\mathrm{a}}$ & $36.72 \pm 0.06^{\mathrm{a}}$ \\
RCC-A & & $48.31 \pm 0.05^{\mathrm{a}}$ & $47.00 \pm 0.03^{\mathrm{a}}$ & $44.96 \pm 0.04^{\mathrm{ab}}$ & $41.82 \pm 0.09^{\mathrm{b}}$ & $37.66 \pm 0.06^{\mathrm{b}}$ \\
RCC-B & & $48.26 \pm 0.02^{\mathrm{a}}$ & $47.47 \pm 0.08^{\mathrm{a}}$ & $45.54 \pm 0.05^{\mathrm{b}}$ & $42.79 \pm 0.03^{\mathrm{c}}$ & $39.99 \pm 0.05^{\mathrm{c}}$ \\
Control & & $15.41 \pm 0.05^{\mathrm{a}}$ & $11.82 \pm 0.02^{\mathrm{ab}}$ & $11.44 \pm 0.02^{\mathrm{c}}$ & $10.33 \pm 0.01^{\mathrm{c}}$ & $6.13 \pm 0.03^{\mathrm{c}}$ \\
RCC-A & $a^{*}$ & $15.65 \pm 0.04^{\mathrm{a}}$ & $12.78 \pm 0.03^{\mathrm{b}}$ & $7.45 \pm 0.03^{\mathrm{a}}$ & $4.46 \pm 0.02^{\mathrm{a}}$ & $2.93 \pm 0.08^{\mathrm{a}}$ \\
RCC-B & & $15.20 \pm 0.04^{\mathrm{a}}$ & $11.12 \pm 0.04^{\mathrm{a}}$ & $8.63 \pm 0.07^{\mathrm{b}}$ & $6.42 \pm 0.02^{\mathrm{b}}$ & $4.76 \pm 0.04^{\mathrm{b}}$ \\
Control & & $6.48 \pm 0.04^{\mathrm{a}}$ & $4.14 \pm 0.05^{\mathrm{a}}$ & $2.43 \pm 0.02^{\mathrm{a}}$ & $1.31 \pm 0.08^{\mathrm{a}}$ & $-0.43 \pm 0.05^{\mathrm{a}}$ \\
RCC-A & $\mathrm{b}^{*}$ & $6.75 \pm 0.04^{\mathrm{a}}$ & $5.54 \pm 0.08^{\mathrm{b}}$ & $5.45 \pm 0.07^{\mathrm{b}}$ & $2.81 \pm 0.01^{\mathrm{b}}$ & $0.58 \pm 0.06^{\mathrm{b}}$ \\
RCC-B & & $6.61 \pm 0.02^{\mathrm{a}}$ & $5.89 \pm 0.02^{\mathrm{b}}$ & $5.92 \pm 0.03^{\mathrm{b}}$ & $4.69 \pm 0.06^{\mathrm{c}}$ & $2.56 \pm 0.02^{\mathrm{c}}$ \\
\hline
\end{tabular}

All the values are mean $\pm \mathrm{SD}, L^{*}$ : lightness, $a^{*}$ : redness, $b^{*}$ : yellowness, letters a-c are given according to the increasing mean values; values for each parameter sharing the same letter in each column represents non significance difference at $p>0.05$; values for each parameter sharing different letter in each column represents significance difference at $p<0.05$. 
The $b^{*}$ values of all the samples increased in a consistent manner with the storage time. After 8 days of storage, the $b^{*}$ values of RCC-A and RCC-B treated samples increased significantly when compared to $C$ samples. The yellowness of the meat was, thus, perhaps because of the color of the plant extracts. With respect to lightness, a subsequent decrease was observed for all meat samples; however, it remained stable in RCC-B treated samples when compared to control and RCC-A samples.

The results of the current study demonstrate that RCC extracts do not have a strong impact on color changes $\left(L^{*}, a^{*}, b^{*}\right.$ values) in meat during storage. It had been described that red cabbage extracts, rich in anthocyanins, improve the red color of beef. In addition, [42] noted a decrease in color parameters, attributed to lipid oxidation, which may induce color changes in meat during storage. Although, in the current study, TBARS values were significantly lower for RCC-A and RCC-B meat samples as compared to the $C$ samples. Moreover, the inclusion of natural plant extracts may instigate changes in the color parameters due to their own characteristic color.

\subsubsection{Textural Analysis}

Texture plays a crucial role in the value of meat in terms of appearance. Hardness or tenderness has been observed as the most important attribute among texture characteristics to satisfy the consumer's preference. Hardness or tenderness of meat can be defined as the force required to obtain a given distortion or a perforation in a product [43]. Therefore, to evaluate the meat quality, hardness was performed with other textural characteristics, such as cohesiveness, gumminess, springiness, and chewiness. Table 7 depicts the texture analysis. All texture characteristics undergo some changes during storage. Generally, all treatments and control samples showed no significant differences $(p<0.05)$ for texture characteristics throughout the storage period. With respect to effect of RCC extract, the RCC-B treated samples depicted a lower hardness, gumminess, and chewiness than the RCC-A and control samples after he fourth and eighth day of storage $(p<0.05)$. In general, hardness and chewiness are positively correlated; with the decrease of hardness, chewiness also decreased by the end of storage period. Cohesiveness and springiness were also lower in RCC-B as compared to RCC-A and C samples. According to Lund et al. [44], meat hardness could be ascribed to a higher influence in protein oxidation reactions, leading to the generation of crosslinking and polymerization in proteins [44].

Table 7. Texture profile analysis of RC extract on muscle of beef meat during storage at $4{ }^{\circ} \mathrm{C}$. All the values are mean $\pm \mathrm{SD}$; letters $\mathbf{a}-\mathbf{c}$ are given according to the increasing mean values; values for each parameter sharing same letter in each column represents non significance difference at $p>0.05$; values for each parameter sharing different letter in each column represents significance difference at $p<0.05$.

\begin{tabular}{|c|c|c|c|c|c|c|}
\hline Days & Treatments & \multicolumn{5}{|c|}{ Texture parameters } \\
\hline \multirow{4}{*}{ Oth } & Control & $1160 \pm 0.02^{\mathrm{a}}$ & $0.53 \pm 0.03^{a}$ & $1.61 \pm 0.01^{\mathrm{a}}$ & $10.9 \pm 0.05^{\mathrm{a}}$ & $583 \pm 0.03^{\mathrm{a}}$ \\
\hline & RCC-A & $1190 \pm 0.04^{\mathrm{a}}$ & $0.53 \pm 0.01^{\mathrm{a}}$ & $1.53 \pm 0.03^{a}$ & $10.9 \pm 0.06^{\mathrm{a}}$ & $590 \pm 0.04^{\mathrm{a}}$ \\
\hline & RCC-B & $1185 \pm 0.05^{\mathrm{a}}$ & $0.56 \pm 0.03^{\mathrm{a}}$ & $1.42 \pm 0.03^{\mathrm{a}}$ & $10.4 \pm 0.04^{\mathrm{a}}$ & $559 \pm 0.05^{\mathrm{a}}$ \\
\hline & Control & $810 \pm 0.04^{\mathrm{a}}$ & $0.74 \pm 0.02^{\mathrm{a}}$ & $1.78 \pm 0.02^{\mathrm{a}}$ & $10.5 \pm 0.03^{\mathrm{a}}$ & $599 \pm 0.01^{\mathrm{a}}$ \\
\hline 4 th & Control & $710 \pm 0.03^{\mathrm{a}}$ & $0.56 \pm 0.05^{\mathrm{a}}$ & $1.27 \pm 0.01^{\mathrm{a}}$ & $6.30 \pm 0.03^{a}$ & $406 \pm 0.05^{\mathrm{a}}$ \\
\hline \multirow[t]{3}{*}{8 th } & RCC-A & $805 \pm 0.05^{\mathrm{b}}$ & $0.53 \pm 0.04^{\mathrm{a}}$ & $1.13 \pm 0.03^{a}$ & $11.8 \pm 0.05^{\mathrm{b}}$ & $561 \pm 0.06^{b}$ \\
\hline & RCC-B & $855 \pm 0.04^{b}$ & $0.59 \pm 0.05^{\mathrm{a}}$ & $1.48 \pm 0.02^{\mathrm{a}}$ & $5.20 \pm 0.03^{b}$ & $557 \pm 0.07^{\mathrm{b}}$ \\
\hline & Control & $500 \pm 0.06^{\mathrm{a}}$ & $0.97 \pm 0.03^{\mathrm{a}}$ & $0.81 \pm 0.04^{\mathrm{a}}$ & $5.00 \pm 0.01^{b}$ & $380 \pm 0.03^{\mathrm{a}}$ \\
\hline 12th & RCC-A & $600 \pm 0.03^{b}$ & $0.74 \pm 0.01^{\mathrm{a}}$ & $1.45 \pm 0.03^{\mathrm{a}}$ & $9.40 \pm 0.04^{b}$ & $400 \pm 0.03^{\mathrm{a}}$ \\
\hline 16th & RCC-B & $530 \pm 0.03^{b}$ & $0.32 \pm 0.02^{\mathrm{a}}$ & $2.78 \pm 0.05^{\mathrm{a}}$ & $18.8 \pm 0.00^{b}$ & $389 \pm 0.03^{b}$ \\
\hline
\end{tabular}

In summary, our results demonstrate the effectiveness of RCC extract in inhibiting microbial growth, reducing lipid oxidation, maintaining organoleptic properties, and extending the shelf life of 
raw beef meat during storage at $4{ }^{\circ} \mathrm{C}$ for 16 days. Current trends of food preservation, considering consumer preference, lead to a depletion in the use of synthetic preservatives for natural additives. In addition, natural antimicrobial compounds from plant sources, such as RC, could effectively deplete the number of microorganisms tested in this study. Therefore, RCC extract application in the development of novel functional healthy meat products may be highly valuable and desirable in the meat industry. However, the use of natural extracts in meat products could be restricted because the addition of high amounts can adversely affect the organoleptic properties of the product. Hence, further studies are required to investigate the antimicrobial effects of concentration below sensorial thresholds and the acceptable level of such natural extracts in the meat industry.

Supplementary Materials: The following are available online at http://www.mdpi.com/2304-8158/9/5/568/s1, Figure S1: GC-MS chromatogram of RCC extract, Table S1: Quantitative phytochemical analysis of different extracts of RC, Table S2: Antimicrobial activity of the compounds present in RC.

Author Contributions: Conceptualization: M.R., R.C., D.-H.O.; Data curation: M.R.; Formal Analysis: M.R., K.B., S.W., J.-R.K., D.Y.; Investigation: M.R., R.C., D.-H.O.; Methodology: M.R., R.C.; Software: M.R., K.S.; Validation: M.R.; Visualization: M.R., M.-H.W., D.-H.O.; Writing-original draft: M.R.; Writing-review \& editing: M.R., R.C.; Funding acquisition: D.-H.O.; Project administration: D.-H.O.; Resources: D.-H.O.; Supervision: D.-H.O. All authors have read and agreed to the published version of the manuscript.

Funding: This research work was supported by a grant from the Brain Korea (BK) 21 Plus Project (Grant No. 22A20153713433), funded by the Korean Government, Republic of Korea. The part of this work was supported by Korea Research Fellowship Program through the National Research Foundation of Korea (NRF) funded by the Ministry of Science, in Young Researchers Program (2018007551) (http://www.nrf.re.kr/eng/main).

Acknowledgments: We thank Park-Yong IK (Kangwon National University, Central laboratory) for technical support for SEM analysis.

Conflicts of Interest: The authors declare that they do not have any conflict of interest.

Ethical Statement: This study does not involve any human or animal testing.

\section{References}

1. Aziz, M.; Karboune, S. Natural antimicrobial/antioxidant agents in meat and poultry products as well as fruits and vegetables: A review. Crit. Rev. Food Sci. Nutr. 2018, 58, 486-511. [CrossRef] [PubMed]

2. Godfray, H.C.J.; Aveyard, P.; Garnett, T.; Hall, J.W.; Key, T.J.; Lorimer, J.; Pierrehumbert, R.T.; Scarborough, P.; Springmann, M.; Jebb, S.A. Meat consumption, health, and the environment. Science 2018, 361, eaam5324. [CrossRef] [PubMed]

3. Omoruyi, I.M.; Uwadiae, E.; Mulade, G.; Omoruku, E. Shiga toxin producing strains of Escherichia coli (STEC) associated with beef products and its potential pathogenic effect. Microbiol. Res. J. Int. 2018, 1-7. [CrossRef] [PubMed]

4. Gokoglu, N. Novel natural food preservatives and applications in seafood preservation: A review. J. Sci. Food Agri. 2019, 99, 2068-2077. [CrossRef] [PubMed]

5. Hintz, T.; Matthews, K.K.; Di, R. The use of plant antimicrobial compounds for food preservation. BioMed Res. Int. 2015. [CrossRef]

6. Rubab, M.; Chellia, R.; Saravanakumar, K.; Mandava, S.; Khan, I.; Tango, C.N.; Hussain, M.S.; Daliri, E.B.-M.; Kim, S.-H.; Ramakrishnan, S.R.; et al. Preservative effect of Chinese cabbage (Brassica rapa subsp. pekinensis) extract on their molecular docking, antioxidant and antimicrobial properties. PLOS ONE 2018, 13, e0203306. [CrossRef]

7. Bakari, S.; Ncir, M.; Felhi, S.; Hajlaoui, H.; Saoudi, M.; Gharsallah, N.; Kadri, A. Chemical composition and in vitro evaluation of total phenolic, flavonoid, and antioxidant properties of essential oil and solvent extract from the aerial parts of Teucrium polium grown in Tunisia. Food Sci. Biotechnol. 2015, 24, 1943-1949. [CrossRef]

8. Bussmann, R.W.; Malca-García, G.; Glenn, A.; Sharon, D.; Chait, G.; Díaz, D.; Pourmand, K.; Jonat, B.; Somogy, S.; Guardado, G.; et al. Minimum inhibitory concentrations of medicinal plants used in Northern Peru as antibacterial remedies. J. Ethnopharmacol. 2010, 132, 101-108. [CrossRef]

9. Franco-Ulloa, S.; La Sala, G.; Miscione, G.; De Vivo, M. Novel bacterial topoisomerase inhibitors exploit Asp83 and the intrinsic flexibility of the DNA gyrase binding site. Int. J. Mol. Sci. 2018, 19, 453. [CrossRef] 
10. Shakeel, E.; Akhtar, S.; Khan, M.K.A.; Lohani, M.; Arif, J.M.; Siddiqui, M.H. Molecular docking analysis of aplysin analogs targeting survivin protein. Bioinformation 2017, 13, 293. [CrossRef]

11. Chelliah, R.; Choi, J.-G.; Hwang, S.-b.; Park, B.-J.; Daliri, E.B.-M.; Kim, S.-H.; Wei, S.; Ramakrishnan, S.R.; Oh, D.-H. In vitro and in vivo defensive effect of probiotic LAB against Pseudomonas aeruginosa using Caenorhabditis elegans model. Virulence 2018, 9, 1489-1507. [CrossRef] [PubMed]

12. Khan, I.; Tango, C.N.; Oh, D.-H. Development and evaluation of chitosan and its derivative for the shelf life extension of beef meat under refrigeration storage. Int. J. Food Sci. Technol. 2017, 52, 1111-1121. [CrossRef]

13. Barekat, S.; Soltanizadeh, N. Improvement of meat tenderness by simultaneous application of high-intensity ultrasonic radiation and papain treatment. Innov. Food Sci. Emerg. Technol. 2017, 39, 223-229. [CrossRef]

14. Latimer, G.W. Official Methods of Analysis of AOAC International; AOAC International: Washington, DC, USA, 2012.

15. Du, M.; Ahn, D. Effect of antioxidants on the quality of irradiated sausages prepared with turkey thigh meat. Poult. Sci. 2002, 81, 1251-1256. [CrossRef]

16. Lee, K.A.; Kim, K.-T.; Nah, S.-Y.; Chung, M.-S.; Cho, S.; Paik, H.-D. Antimicrobial and antioxidative effects of onion peel extracted by the subcritical water. Food Sci. Biotechnol. 2011, 20, 543-548. [CrossRef]

17. Altemimi, A.; Lakhssassi, N.; Baharlouei, A.; Watson, D.; Lightfoot, D. Phytochemicals: Extraction, isolation, and identification of bioactive compounds from plant extracts. Plants 2017, 6, 42. [CrossRef]

18. Kim, S.-J.; Cho, A.R.; Han, J. Antioxidant and antimicrobial activities of leafy green vegetable extracts and their applications to meat product preservation. Food Control 2013, 29, 112-120. [CrossRef]

19. Köksal, E.; Bursal, E.; Gülçin, İ.; Korkmaz, M.; Çağlayan, C.; Gören, A.C.; Alwasel, S.H. Antioxidant activity and polyphenol content of Turkish thyme (Thymus vulgaris) monitored by liquid chromatography and tandem mass spectrometry. Int. J. Food Prop. 2017, 20, 514-525. [CrossRef]

20. Pietta, P.-G. Flavonoids as antioxidants. J. Nat. Prod. 2000, 63, 1035-1042. [CrossRef]

21. Tsao, R.; Deng, Z. Separation procedures for naturally occurring antioxidant phytochemicals. J. Chromatogr. B 2004, 812, 85-99. [CrossRef]

22. Nićiforović, N.; Mihailović, V.; Mašković, P.; Solujić, S.; Stojković, A.; Muratspahić, D.P. Antioxidant activity of selected plant species; potential new sources of natural antioxidants. Food Chem. Toxicol. 2010, 48, 3125-3130. [CrossRef] [PubMed]

23. Cho, M.; Lee, H.-S.; Kang, I.-J.; Won, M.-H.; You, S. Antioxidant properties of extract and fractions from Enteromorpha prolifera, a type of green seaweed. Food Chem. 2011, 127, 999-1006. [CrossRef] [PubMed]

24. Martysiak-Żurowska, D.; Wenta, W. A comparison of ABTS and DPPH methods for assessing the total antioxidant capacity of human milk. Acta Scient. Polon. Technol. Aliment. 2012, 11, 83-89.

25. Udayaprakash, N.; Ranjithkumar, M.; Deepa, S.; Sripriya, N.; Al-Arfaj, A.A.; Bhuvaneswari, S. Antioxidant, free radical scavenging and GC-MS composition of Cinnamomum iners Reinw. ex Blume. Ind. Crops Prod. 2015, 69, 175-179. [CrossRef]

26. Chemonges, $\mathrm{S}$. The recognition of $\mathrm{LpxC}$ inhibitors as potential antibiotics could revolutionise the management of sepsis in veterinary patients if their unknown biological properties are widely evaluated in suitable animal models. Int. J. Vet. Sci. Med. 2014, 2, 99-102. [CrossRef]

27. Collin, F.; Karkare, S.; Maxwell, A. Exploiting bacterial DNA gyrase as a drug target: Current state and perspectives. Appl. Microbiol. Biotechnol. 2011, 92, 479-497. [CrossRef]

28. Dougherty, T.J.; Nayar, A.; Newman, J.V.; Hopkins, S.; Stone, G.G.; Johnstone, M.; Shapiro, A.B.; Cronin, M.; Reck, F.; Ehmann, D.E. NBTI 5463 is a novel bacterial type II topoisomerase inhibitor with activity against Gram-negative bacteria and in vivo efficacy. Antimicrob. Agents Chemother. 2014, 58, 2657-2664. [CrossRef]

29. Hameed, I.H.; Hussein, H.J.; Kareem, M.A.; Hamad, N.S. Identification of five newly described bioactive chemical compounds in methanolic extract of Mentha viridis by using gas chromatography-mass spectrometry (GC-MS). J. Pharmacog. Phytother. 2015, 7, 107-125.

30. Ibibia, E.T.; Olabisi, K.N.; Oluwagbemiga, O.S. Gas chromatography-mass spectrometric analysis of methanolic leaf extracts of lannea kerstingii and nauclea diderrichii, two medicinal plants used for the treatment of gastrointestinal tract infections. Asian J. Pharm. Clin. Res. 2016, 9, 179-182.

31. Saleem, H.; Htar, T.T.; Naidu, R.; Nawawi, N.S.; Ahmad, I.; Ashraf, M.; Ahemad, N. Biological, chemical and toxicological perspectives on aerial and roots of Filago germanica (L.) huds: Functional approaches for novel phyto-pharmaceuticals. Food Chem. Toxicol. 2019, 123, 363-373. [CrossRef] 
32. Bazargani-Gilani, B.; Aliakbarlu, J.; Tajik, H. Effect of pomegranate juice dipping and chitosan coating enriched with Zataria multiflora Boiss essential oil on the shelf-life of chicken meat during refrigerated storage. Innov. Food Sci. Emerg. Technol. 2015, 29, 280-287. [CrossRef]

33. da Cruz Cabral, L.; Fernández Pinto, V.; Patriarca, A. Application of plant derived compounds to control fungal spoilage and mycotoxin production in foods. Int. J. Food Microbiol. 2013, 166, 1-14. [CrossRef] [PubMed]

34. Nikmaram, N.; Budaraju, S.; Barba, F.J.; Lorenzo, J.M.; Cox, R.B.; Malikarjunan, K.; Roohinejad, S. Application of plant extracts to improve the shelf-life, nutritional and health-related properties of ready-to-eat meat products. Meat Sci. 2018, 145, 245-255. [CrossRef] [PubMed]

35. Koné, A.P.; Desjardins, Y.; Gosselin, A.; Cinq-Mars, D.; Guay, F.; Saucier, L. Plant extracts and essential oil product as feed additives to control rabbit meat microbial quality. Meat Sci. 2019, 150, 111-121. [CrossRef]

36. Fernández-López, J.; Zhi, N.; Aleson-Carbonell, L.; Pérez-Alvarez, J.A.; Kuri, V. Antioxidant and antibacterial activities of natural extracts: Application in beef meatballs. Meat Sci. 2005, 69, 371-380. [CrossRef]

37. Nieto, G.; Díaz, P.; Bañón, S.; Garrido, M.D. Dietary administration of ewe diets with a distillate from rosemary leaves (Rosmarinus officinalis L.): Influence on lamb meat quality. Meat Sci. 2010, 84, 23-29. [CrossRef]

38. Lee, S.-J.; Kim, H.J.; Cheong, S.H.; Kim, Y.-S.; Kim, S.-E.; Hwang, J.-W.; Lee, J.-S.; Moon, S.-H.; Jeon, B.-T.; Park, P.-J. Antioxidative effect of recombinant ice-binding protein (rLeIBP) from Arctic yeast Glaciozyma sp. on lipid peroxidation of Korean beef. Proc. Biochem. 2015, 50, 2099-2104. [CrossRef]

39. Zhang, H.; Wu, J.; Guo, X. Effects of antimicrbial and antioxidant activities of spice extracts on raw chicken meat quality. Food Sci. Human Illnes 2016, 5, 39-48. [CrossRef]

40. Hwang, J.-W.; Cheong, S.H.; Kim, Y.-S.; Lee, J.-W.; You, B.-I.; Moon, S.-H.; Jeon, B.-T.; Park, P.-J. Effects of dietary supplementation of oriental herbal medicine residue and methyl sulfonyl methane on the growth performance and meat quality of ducks. Anim. Prod. Sci. 2017, 57, 948-957. [CrossRef]

41. Lorenzo, J.M.; Sineiro, J.; Amado, I.R.; Franco, D. Influence of natural extracts on the shelf life of modified atmosphere-packaged pork patties. Meat Sci. 2014, 96, 526-534. [CrossRef]

42. Xia, X.; Kong, B.; Liu, Q.; Liu, J. Physicochemical change and protein oxidation in porcine longissimus dorsi as influenced by different freeze-thaw cycles. Meat Sci. 2009, 83, 239-245. [CrossRef] [PubMed]

43. Rahim, H.A.; Ghazali, R. The application of near-infrared spectroscopy for poultry meat grading. In Proceedings of the 2012 IEEE 8th International Colloquium on Signal Processing and its Applications, Melaka, Malaysia, 23-25 March 2012; pp. 58-62.

44. Lund, M.N.; Heinonen, M.; Baron, C.P.; Estevez, M. Protein oxidation in muscle foods: A review. Mol. Nutr. Food Res. 2011, 55, 83-95. [CrossRef] [PubMed] 